\title{
Taxonomic review of Colombian Parodon (Characiformes: Parodontidae), with descriptions of three new species
}

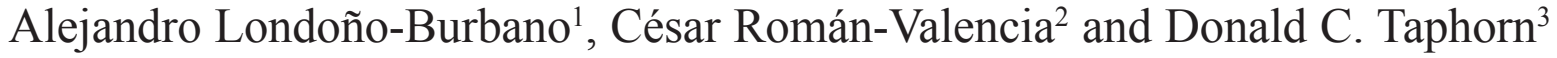

We review species of Parodon Valenciennes, 1850 from the Magdalena, Cauca, Orinoco, Amazonas, Atrato and CaribbeanGuajira River basins of Colombia using meristic and morphological characters. We recognize eight valid species, five previously described: P. apolinari Myers, from the Orinoco River basin; P. buckleyi Boulenger and P. pongoensis (Allen) from the upper Amazon; P. caliensis Boulenger, from the upper Cauca River drainage; and P. suborbitalis Valenciennes, from Lake Maracaibo basin. Three new species are described: $P$. alfonsoi, from the lower Magdalena River drainage; $P$. magdalenensis, from the middle Magdalena and upper Cauca River drainages; and P. atratoensis, from the Atrato River basin. We redescribe Parodon suborbitalis using type specimens and topotypes, and designate lectotypes. A taxonomic key is included for identification of the species, as well as geographic distribution maps.

Espécies de Parodon Valenciennes, 1850 provenientes das bacias dos rios Magdalena, Cauca, Orinoco, Amazonas, Atrato e Caribe-Guajira da Colômbia são revisadas com base em caracteres merísticos e morfológicos. Oito espécies são consideradas válidas, sendo cinco previamente descritas: P. apolinari Myers, da bacia do rio Orinoco, P. buckleyi Boulenger e P. pongoensis (Allen) do alto rio Amazonas, P. caliensis Boulenger do alto rio Cauca e P. suborbitalis Valenciennes da bacia do lago Maracaibo. Três novas espécies são descritas: P. alfonsoi, do baixo rio Magdalena; P. magdalenensis, do médio rio Magdalena e da bacia superior do rio Cauca e P. atratoensis, da bacia do rio Atrato. Parodon suborbitalis é redescrita a partir de espécimes-tipo e topótipos. Designam-se lectótipos de P. suborbitalis. Uma chave para identificação das espécies é incluída, bem como mapas de distribuição geográfica.

Key words: Colombia, Geographic distribution, Neotropical fish, Systematics, Taxonomy.

\section{Introduction}

The small characiform family Parodontidae consists of three genera that include about 29 valid species according to Eschmeyer \& Fong (2011). Tooth characteristics have traditionally been used to define the three parodontid genera: small lateral teeth are present on the sides of the lower jaw of Parodon Valenciennes, but absent in Apareiodon Eigenmann and Saccodon Kner (Eigenmann, 1916; Londoño-Burbano \& Román-Valencia, 2010). The diagnosis of taxa within this family is complicated by several factors: they have relatively small, weak teeth that are easily broken, and thus have frequently been overlooked or misinterpreted; and many species were described without a diagnostic comparison with other species, in very brief, incomplete reports that were sometimes based on erroneous observations (Pavanelli, 2003) leading to nomenclatural uncertainty and instability. Britski (1972) considered the number of tooth cusps as a good character for species identification and pointed out the importance of including osteological characters to better understand the taxonomy of this family and characiforms in general. In parodontids the premaxilla has a series of small rounded multicuspid teeth. The number of cusps on these teeth is diagnostic for Parodon species, but not for Saccodon, which show dental polymorphism (Roberts, 1974a). In recent studies, pigmentation patterns of the body and the type of teeth are the principal morphological differences found to be useful to differentiate species (Jesus et al., 1999; Londoño-Burbano \& Román-Valencia, 2010). Parodontids occur in Panama and in most South American drainages with the exception of those in southern Bahia State on the Atlantic coast of Brazil, Patagonia, and the main channel of the Amazon River (Pavanelli, 2003). Few species of the genus Parodon have been reported from Colombian drainages.

${ }^{1}$ Pontifícia Universidade Católica do Rio Grande do Sul, Laboratório de Sistemática de Vertebrados, Avenida Ipiranga 6681, P. O. Box 1429, 90619-900 Porto Alegre, RS, Brazil. alondonoburbano@gmail.com

${ }^{2}$ Universidad del Quindío, Laboratorio de Ictiología, A. A. 2639, Armenia, Colombia. ceroman@uniquindio.edu.co

${ }^{3} 1822$ North Charles Street, Belleville, Illinois, 62221, USA. taphorn@gmail.com 
Taxonomy of this group of fishes has been poorly studied in western South America. This is also true for Colombia, where few collecting efforts have been made and museum specimens are scarce. The aim of this study is to carry out a taxonomic review of Colombian Parodon, based on morphometric, meristic, and osteological characters for their descriptions and diagnoses and provide a key to identify the species.

\section{Material and Methods}

Counts and measurements follow Pavanelli \& Britski (2003) and were taken using a stereoscope, needle and digital calipers with $0.1 \mathrm{~mm}$ precision. Except for counts of teeth and tooth cusps, counts and measurements were taken from the left side of specimens when possible. A total of 36 morphometric and 18 counts were taken. The Scion Image program for Windows was used to take counts and measurements from photographs of types and specimens unavailable for loan. Measurements are presented in the tables as percents of standard (SL) or head length (HL). Statistics were calculated using Microsoft Excel. Because Parodon species do not vary much in terms of morphometrics, species are distinguished and described using meristics, pigmentation patterns, body and fin shapes and tooth morphology, mainly. In both descriptions of type and nontype localities the altitude is given as meters above sea level (masl); coordinates of type localities were taken from maps locating the collecting sites given in the original descriptions. Only adult and well preserved specimens were used for the type series of new species, juveniles and poorly preserved material examined are listed as non type material.

Counts are compared using Tukey or box plots made with Past software version 1.52 for Windows and using the arithmetic mean as the central tendency for meristic counts and the maximum and minimum values for each. Osteological observations were made on specimens cleared and stained using methods described by Taylor \& van Dyke (1985).

The material examined section for each species is organized thusly: country, acronym of the institution, catalog number, number of specimens examined in Arabic numerals, followed by the number of cleared and stained specimens (if available) in Arabic numerals, and indicated by c\&s, followed by the range of standard length for each lot, and drainage. For each lot locality information is presented as follows: department, state or province, locality, date of collection.

Pigmentation patterns were described from specimens preserved in $70 \%$ ethanol. Sexually dimorphic breeding tubercles (present only in males) were determined according to Wiley \& Collette (1970). Ecological data on maximum size, habitat type, distribution and sexual dimorphism are also presented.

Diagnostic characters cited for species that are not listed on the item "Comparative material examined", were taken from their original and subsequent descriptions. Institutional acronyms follow Ferraris (2007), except for CIUA, Colección de Ictiología del Instituto de Biología de la Universidad de Antioquia, Medellín, Colombia; IAvH, Instituto de
Investigación de Recursos Biológicos Alexander von Humboldt, Villa de Leyva, Boyacá; and ICN - Instituto de Ciencias Naturales, Museo de Historia Natural, Facultad de Ciencias, Universidad Nacional de Colombia, Bogotá.

\section{Parodon alfonsoi, new species Fig. 1}

Holotype. CIUA 1125, 103.4 mm SL, Colombia, Cesar, Municipio La Jagua de Ibiricó, lower río Magdalena drainage, río Tucuy, tributary to the río Calenturitas, $9^{\circ} 37^{\prime} \mathrm{N} 73^{\circ} 17^{\prime} \mathrm{W}$, elevation 117 masl, 28 Mar 2007, U. Jaramillo.

Paratypes. CIUA 691, 10, 84.2-106.9 mm SL; IUQ 2614, 2, 89.5$94.2 \mathrm{~mm}$ SL; IUQ 2546, 2 c\&s, 87.3-95.1 mm SL, all collected with the holotype.

Diagnosis. Parodon alfonsoi differs from its congeners in having a silvery blotch beneath the eye ( $v s$. silvery suborbital blotch absent); a lateral stripe with conspicuous, dark, vertical projections along almost its entire length (from the opercle to the area above the anal-fin base origin) (vs. lateral stripe with inconspicuous vertical projections along its entire length or without projections). From $P$. suborbitalis it can be distinguished by the greater number of preanal scales (27-30 vs. 24-27); by the lower number of cusps on premaxillary teeth (11-14 vs. 15-17); and by the lower number of branched pectoral-fin rays (11-14 vs. 14-17). It differs from P. moreirai, P. pongoensis, $P$. caliensis, and $P$. apolinari by the presence of a lateral stripe with zigzag projections ( $v s$. absence of lateral stripe with zigzag projections). From $P$. hilarii it is differentiated by the straight edge of the premaxillary teeth (vs. slightly rounded) and length of projections of lateral stripe (three scales $v$ s. two scales). From P. nasus it is distinguished by elongated projections ( $v s$. rounded projections) and in having the lateral stripe extending to the distal tip of the medial caudal rays ( $v s$. absence of medial caudal rays with dark projection). It also differs in the number of preanal scales (27-30 vs. fewer than 27, except in $P$. hilarii which has up to 28); greater caudal peduncle depth (13.3-16.3\% SL vs. 12.9-14\% in P. atratoensis, $10.7-13.9 \%$ in $P$. buckleyi and $10.4-12.7 \%$ in P. pongoensis); in having no dark spots above the lateral stripe ( $v s$. spots present above lateral stripe except in P. bifasciatus); and by the number of cusps in premaxillary teeth (12-14 vs. 15-19 in P. carrikeri; 7-12 in P. bifasciatus). It can be differentiated from $P$. guyanensis by the number of teeth in the premaxilla (four $v s$. five).

Description: Morphometric and meristic data given in Tables 1 and 2, respectively. Body cylindrical. Dorsal profile of trunk convex from posterior margin of supraoccipital process to dorsal-fin origin, angle diminishing up to adipose-fin origin, then concave to base of upper caudal-fin lobe. Ventral profile of trunk rounded to base of pelvic fins, then straight to posterior margin of anal fin and concave from that point to origin of lower caudal-fin lobe. Dorsal profile of head slightly concave 


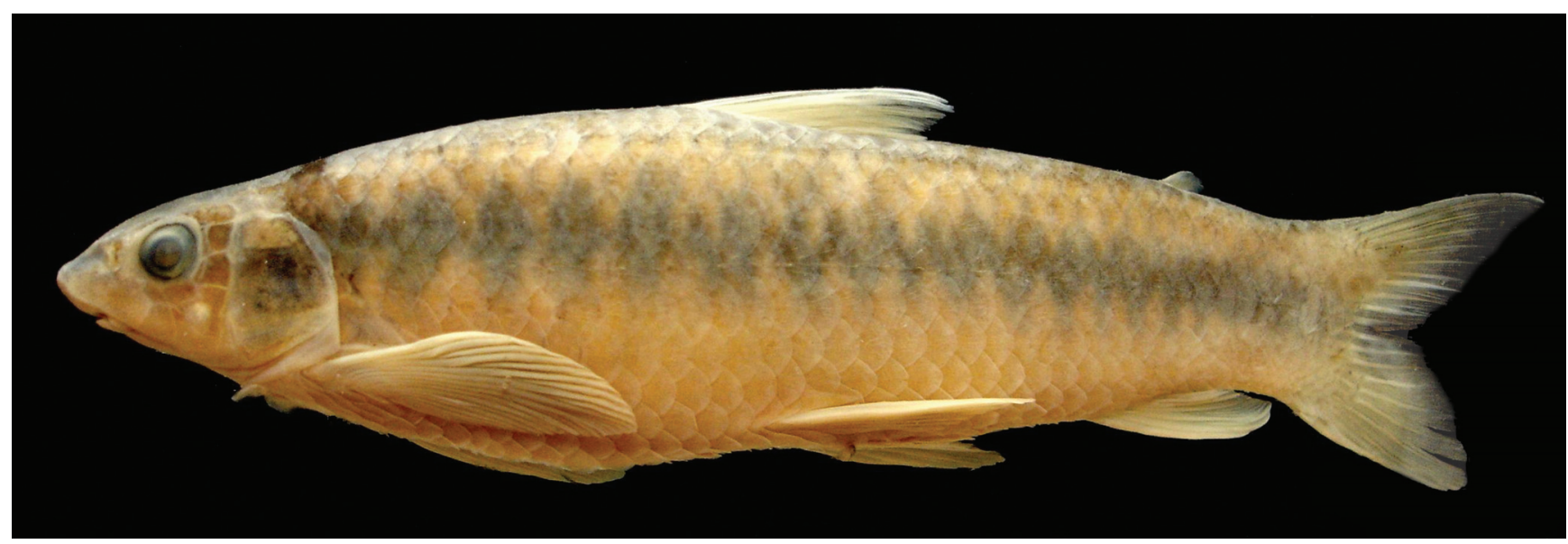

Fig. 1. Parodon alfonsoi, Holotype, CIUA 1125, 103.4 mm SL. Colombia, Tucuy River, tributary of the Calenturitas River, lower Magdalena, La Jagua de Ibiricó.

from snout to anterior nares, then straight until supraoccipital. Ventral profile of head straight to isthmus; branchial membranes united to each other and free from isthmus. Eyes lateral; nares at height of eye, round, with membrane of skin that separates anterior and posterior orifices. Mouth ventral, upper lip absent.

Premaxillary hemiseries of four teeth arranged in straight line, each tooth with 11-14 small cusps. Teeth fit into lower jaw. Maxilla with one or two multicuspid teeth, smaller than premaxillary teeth and deeply embedded (about half of tooth exposed) in soft tissue covering bone. Lower jaw with 1-3 outwardly curved laterally located teeth without cusps, not visible when mouth closed.

Pectoral fin short, not reaching pelvic-fin origins, located at vertical passing through posterior part of opercle, truncate, with fifth and sixth branched rays longest. Pelvic fin not reaching anal-fin origin, but reaching one scale beyond genital pore; pelvic fin inserted at vertical through middle of dorsal-fin base. Dorsal fin truncate, with first three branched rays longer and first unbranched ray completely dark, shorter than others. Dorsal-fin origin at vertical passing anterior to pelvic fin insertion but posterior to pectoral fin. Anal-fin origin at vertical passing through third scale anterior to adipose-fin origin. Anal fin not reaching origin of lower caudal-fin lobe. Caudal fin bilobed, with upper lobe little longer than lower, scales on base extending onto proximal $1 / 3$ of fin.

Lateral line with $36-38$ pored scales that reach to caudalfin base and sometimes extend onto basal third of that fin; scales in predorsal and ventral regions distributed regularly, axillary scale present, one or two normal scales in length.

Color in alcohol. Dorsal surface of snout and head gray, lighter yellow below horizontal through ventral margin of eye. Dorsum of body gray to black, darker than rest of body. Upper region of opercle with lighter blotch that contacts upper posterior part of infraorbital five. One, often rounded, conspicuous silvery spot (sometimes divided into two unequally sized spots) just below eye.

Lateral portion of body dark yellow, lighter yellow below lateral stripe that consists of 18-20 horizontally elongate spots forming zigzag stripe with dorsal and ventral projections. This stripe better defined in anterior portion to level of dorsal-fin origin; spots oblique in part from posterior margin of dorsalfin base to level of vertical through scale just anterior to analfin origin, spots vertical posterior to that point, and narrower than those on anterior portion of body. Lateral stripe extending on to middle caudal-fin rays.

Dorsal part of body separated from lateral stripe by lighter yellow row of scales that extends from snout to base of caudal fin, dorsal bands absent, color uniform. Holotype with transverse band at terminus of supraoccipital that extends to upper portion of opercle on each side of head (not observed in other specimens).

Pectoral and pelvic fin with black or brown chromatophores scattered on first rays but without forming distinct spots or bands. First unbranched dorsal-fin ray dark for all its length, black chromatophores present on all dorsalfin rays but without forming spots or bars. All caudal-fin rays with chromatophores, densest along posterior margin, and reaching their distal portion but not forming spots or bars; middle rays black to their tips. Anal fin hyaline. Adipose fin with black base and white spot in central portion. Ventral part of body lighter, without spots or chromatophores.

Sexual dimorphism. Small breeding tubercles present on head, most numerous and conspicuous on ventral surface and snout, extending to tip of supraoccipital process where tubercles are smaller, less numerous and hard to see without magnification; observed in males between 84 and $107 \mathrm{~mm}$ SL (all adults).

Distribution. Known from the río Tucuy, a tributary of the río Calenturitas, lower río Magdalena basin (Fig. 2).

Etymology. This species is named alfonsoi, to honor Alfonso Londoño Orozco, father of the first author (AL-B), for his support and personal inspiration through the years.

Comments. The color pattern and shape of the teeth in this new species are most similar to Parodon suborbitalis, but it 
Table 1. Morphometric measurements as percent of SL and HL for Parodon alfonsoi $(\mathrm{n}=14)$, P. atratoensis $(\mathrm{n}=5)$, P. magdalenensis $(\mathrm{n}=70)$, and P. suborbitalis $(\mathrm{n}=53)$. Hol. $=$ holotype, Lect. $=$ Lectotype. Standard and total length in $\mathrm{mm}$.

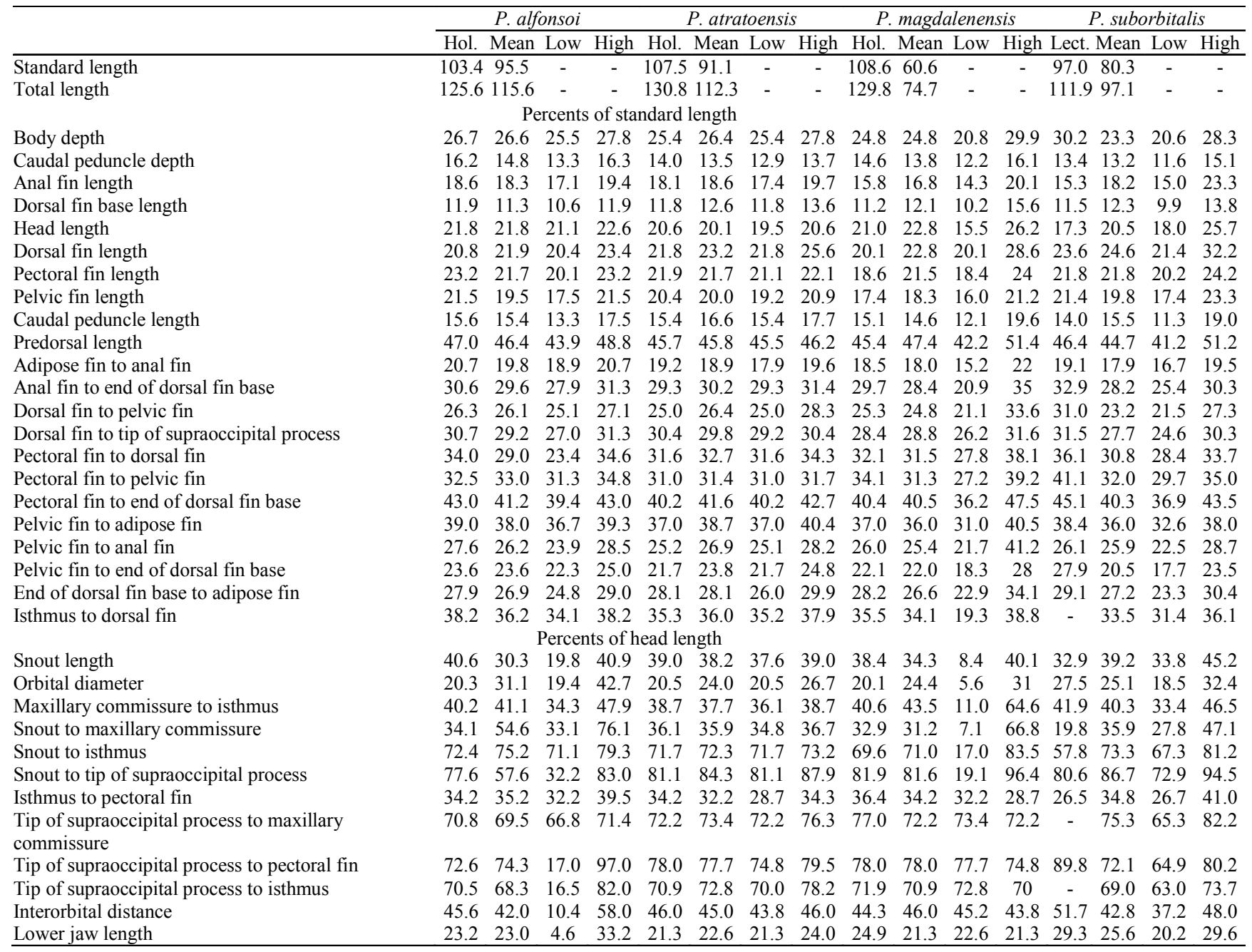

Table 2. Counts for Parodon alfonsoi $(\mathrm{n}=14)$, P. atratoensis $(\mathrm{n}=5)$, . magdalenensis $(\mathrm{n}=70)$, and P. suborbitalis $(\mathrm{n}=53)$.

\begin{tabular}{|c|c|c|c|c|c|c|c|c|c|c|c|c|}
\hline & \multicolumn{3}{|c|}{ P. alfonsoi } & \multicolumn{3}{|c|}{ P. atratoensis } & \multicolumn{3}{|c|}{ P. magdalenensis } & \multicolumn{3}{|c|}{ P. suborbitalis } \\
\hline & Low & High & Holotype & Low & High & Holotype & Low & High & Holotype & Low & High & Lectotype \\
\hline Premaxillary teeth cusps & 12 & 14 & 13 & 12 & 13 & 13 & 11 & 15 & 12 & 15 & 17 & - \\
\hline Maxillary teeth & 2 & 2 & 2 & 2 & 2 & 2 & 2 & 2 & 2 & 1 & 2 & - \\
\hline Premaxillary teeth & 4 & 4 & 4 & 4 & 4 & 4 & 4 & 4 & 4 & 4 & 4 & - \\
\hline Lower jaw teeth & 2 & 3 & 2 & 1 & 3 & 1 & 1 & 3 & 3 & 2 & 3 & 3 \\
\hline Circumpeduncular scales & 16 & 16 & 16 & 16 & 16 & 16 & 16 & 16 & 16 & 16 & 16 & - \\
\hline Lateral line scales & 36 & 38 & 37 & 37 & 38 & 37 & 35 & 38 & 37 & 37 & 39 & 38 \\
\hline Scales between dorsal fin and adipose fin & 11 & 13 & 12 & 11 & 12 & 12 & 10 & 13 & 12 & 10 & 13 & 11 \\
\hline Post-adipose scales & 7 & 9 & 8 & 7 & 8 & 8 & 6 & 8 & 8 & 7 & 8 & 6 \\
\hline Post-anal scales & 3 & 4 & 3 & 2 & 2 & 2 & 3 & 4 & 3 & 2 & 4 & - \\
\hline Preanal scales & 27 & 30 & 27 & 23 & 24 & 24 & 24 & 27 & 25 & 24 & 27 & - \\
\hline Predorsal scales & 11 & 12 & 12 & 11 & 12 & 11 & 11 & 13 & 12 & 11 & 12 & 12 \\
\hline Rows of scales below the lateral line & 4 & 4 & 4 & 4 & 4 & 4 & 4 & 4 & 4 & 4 & 4 & 4 \\
\hline Rows of scales above the lateral line & 4 & 4 & 4 & 4 & 4 & 4 & 4 & 4 & 4 & 4 & 4 & 4 \\
\hline Anal fin rays & i,7 & $\mathrm{i}, 7$ & i,7 & ii,6 & ii,7 & $\mathrm{i}, 7$ & $\mathrm{i}, 6$ & $\mathrm{i}, 8$ & $\mathrm{i}, 7$ & i,7 & $\mathrm{i}, 8$ & - \\
\hline Caudal fin rays & $\mathrm{i}, 17, \mathrm{i}$ & $\mathrm{i}, 17, \mathrm{i}$ & $\mathrm{i}, 17, \mathrm{i}$ & $\mathrm{i}, 17, \mathrm{i}$ & $\mathrm{i}, 17, \mathrm{i}$ & $\mathrm{i}, 17, \mathrm{i}$ & $\mathrm{i}, 17, \mathrm{i}$ & $\mathrm{i}, 17, \mathrm{i}$ & $\mathrm{i}, 17, \mathrm{i}$ & $\mathrm{i}, 16, \mathrm{i}$ & $\mathrm{i}, 17, \mathrm{i}$ & - \\
\hline Dorsal fin rays & ii, 10 & ii, 10 & ii, 10 & $\mathrm{i}, 10$ & $\mathrm{i}, 10$ & $\mathrm{i}, 10$ & $\mathrm{i}, 10$ & ii, 10 & ii, 10 & ii, 10 & ii, 10 & - \\
\hline Pectoral fin rays & $\mathrm{i}, 12$ & $\mathrm{i}, 14$ & $\mathrm{i}, 13$ & $\mathrm{i}, 12$ & $\mathrm{i}, 13$ & $\mathrm{i}, 12$ & $\mathrm{i}, 11$ & $\mathrm{i}, 14$ & $\mathrm{i}, 12$ & $\mathrm{i}, 14$ & $\mathrm{i}, 17$ & - \\
\hline Pelvic fin rays & $\mathrm{i}, 7$ & $\mathrm{i}, 7$ & $\mathrm{i}, 7$ & $\mathrm{i}, 7$ & $\mathrm{i}, 7$ & $\mathrm{i}, 7$ & $\mathrm{i}, 7$ & $\mathrm{i}, 7$ & $\mathrm{i}, 7$ & $\mathrm{i}, 6$ & $\mathrm{i}, 7$ & - \\
\hline
\end{tabular}




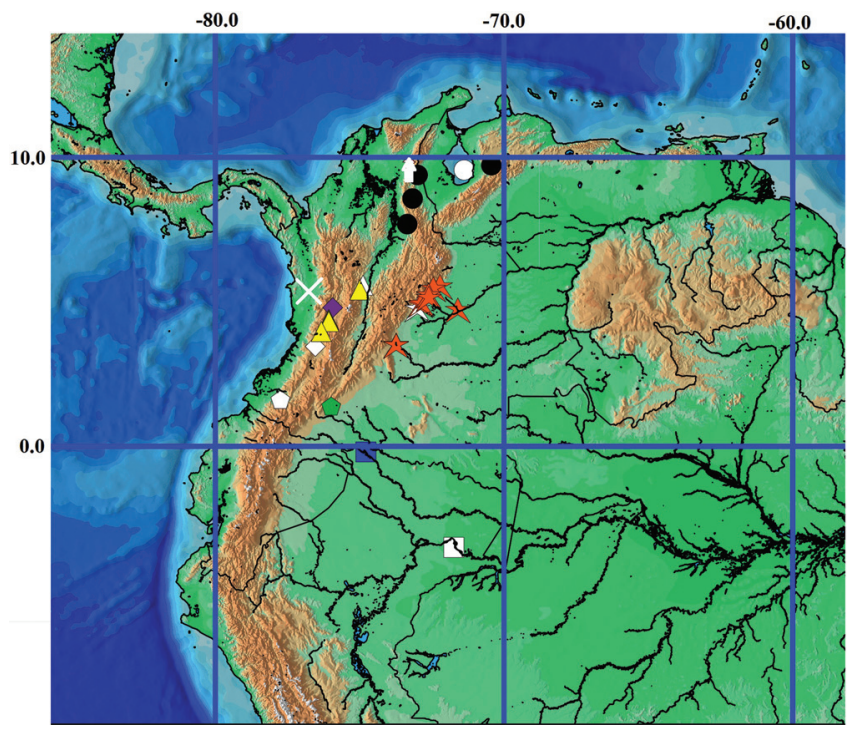

Fig. 2. Distribution of Parodon species in Colombia. Parodon apolinari (star); P. buckleyi (square); P. caliensis (diamond); P. pongoensis (pentagon); P. suborbitalis (circle); P. alfonsoi (arrow up); P. magdalenensis (triangle); P. atratoensis (X). Each symbol may represent more than one locality. Open symbols represents type locality of each species.

differs from that species by the distance from the isthmus to the union of the maxilla with the anterior part of the dentary; by the distance from the snout to the isthmus; by the greater number of preanal scales (27-30 vs. 24-27); by the lower number of cusps on premaxillary teeth (11-14 vs. 15-17); and by the lower number of branched pectoral-fin rays (12-14 vs. 14-16). Its distribution suggests that this population from the Tucuy River was once connected to the Maracaibo Lake basin, before the uprising of the Perija Mountains, when the Magdalena and Maracaibo formed one hydrological system.

One specimen of $P$. alfonsoi had 25 preanal scales, but for most specimens the count is useful to distinguish this species. One specimen of $P$. caliensis had 29 preanal scales, but that species is not present in any portion of the Magdalena Basin.

\section{Parodon apolinari Myers, 1930}

Fig. 3

Parodon apolinari Myers, 1930: 66 (type locality: Guaicaramo, Guavio River, Orinoco basin, Colombia, Holotype: CASSU 23725). Schultz, 1944: 289 (key, diagnosis, table with morphometric data). Wiley \& Collette, 1970: 165 (discussion of nuptial tubercles as first described by Myers [1930]). Géry, 1977: 202, 208 (key, assignation to subgenus Parodon; live photograph identified as $P$. suborbitalis). Pavanelli, 2003: 48 (distribution; localization of type material; maximum size, common names).

Parodon (Nematoparodon) apolinari.- Fowler, 1943: 226 (monotypic subgenus Nematoparodon described with $P$. apolinari designated as type-species, redescription, illustration of body and head).

Diagnosis. Parodon apolinari differs from all congeners in having 14-17 dark vertical bars on sides of body, 1-2 scales wide, not in contact with each other, (vs. non-touching vertical bars and vertically elongate spots absent, except in P. caliensis); in adult males first dorsal-fin rays longer than others, sometimes reaching adipose fin when depressed ( $v s$. not that long, never reaching the adipose fin); sexually mature males with nuptial tubercles large and numerous, especially abundant on snout (vs. tubercles absent, or greatly reduced and small).

Description. Morphometric and meristic data given in Tables 3 and 4, respectively. Body stout. Dorsal profile of trunk convex from snout to adipose-fin origin, then concave to caudal fin. Ventral profile straight. Dorsal profile of head slightly convex from tip of snout to tip of supraoccipital process. Ventral profile of head straight; snout prominent. Isthmus located at vertical through anterior margin of opercle; branchial membranes united to each other but free from isthmus. Eyes lateral; nares at height of eye, elongate ovals, sometimes with flap of skin separating orifices, anterior nare larger than posterior. Mouth ventral, upper lip absent. Ventral profile of trunk rounded from isthmus to anal-fin origin, then convex to caudal fin. Caudal peduncle compressed.

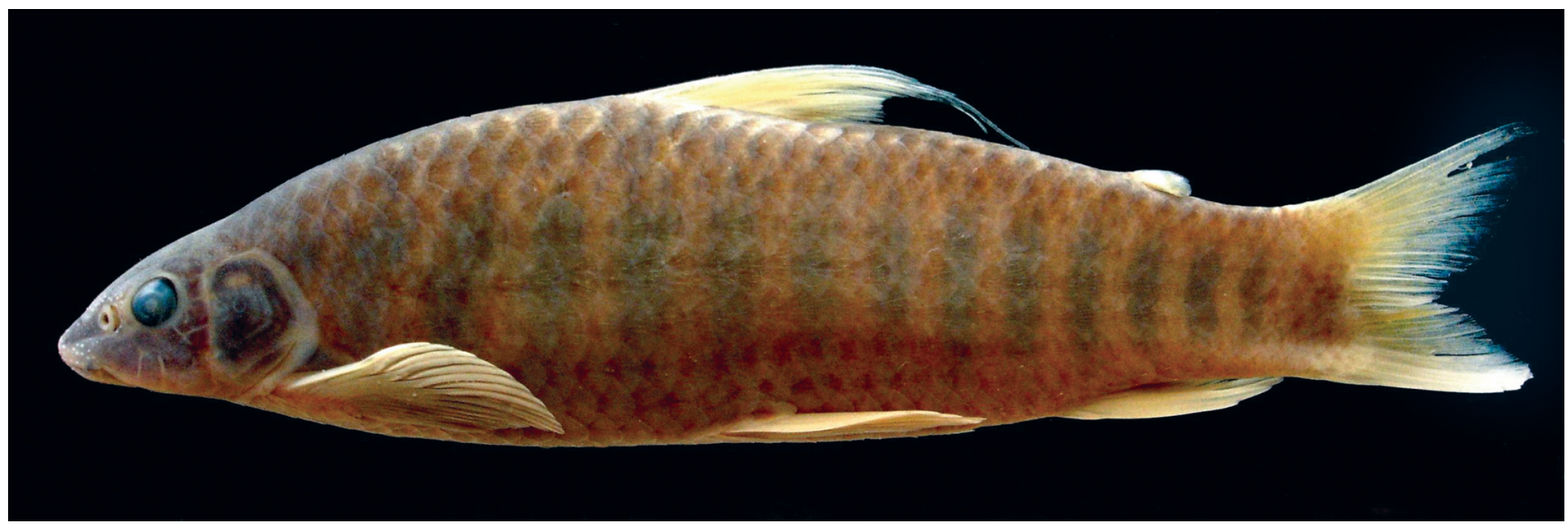

Fig. 3. Parodon apolinari, IAvH 3438; $101.9 \mathrm{~mm}$ SL. Colombia, Orinoco basin, Chiquito River at bridge on the Villao-Yopal road. 
Premaxillary hemiseries with four teeth, their inferior margin straight and with 14-26 small cusps. Teeth fitting into space provided in lower jaw. Maxilla with 1-2 teeth, smaller than those of premaxilla, usually half buried in surrounding soft tissue and often hard to see. Dentary with 2-3 laterally positioned teeth without cusps that curve outward, larger than those of premaxillary, and not visible when mouth closed.

Pectoral fin usually long (Table 2), in some individuals reaching vertical through dorsal-fin origin (in this case, fin rays of other fins usually elongate as well) but not reaching pelvicfin insertions, truncate, with insertion at vertical through second predorsal scale posterior to tip of supraoccipital process; fifth branched ray longest. Pelvic fin just reaching genital pore, but not anal-fin origin; truncate with insertions at vertical through or anterior to middle of dorsal-fin base, second branched ray longest. Longest anal-fin rays reaching caudal fin. Anal fin truncate; its origin at vertical through second or third scale anterior to adipose fin, its first two branched rays longer than others. Dorsal fin truncate, origin at vertical through point half way between pectoral and pelvic-fin insertions, sometimes reaching adipose when depressed, first two branched rays longer (sometimes twice as long) than others. Adipose-fin origin at vertical through posterior anal-fin base. Caudal fin bilobed, with lobes of equal length, basal third scaled, with scales extending farther out lower lobe, usually to cover half.

Lateral line with 35-38 pored scales, sometimes extending onto scaled portion of caudal fin. Scales distributed regularly in predorsal and ventral areas. Axillary scale present, two to three normal scales in length.

Color in alcohol. Dorsal surface of snout and head dark brown but without melanophores, lighter brown below horizontal through ventral margin of eye. Dorsum of body crossed by 14-17 dark transverse bars separated by spaces of yellow or light brown; first bar at tip of supraoccipital process, last near of caudal fin.

Base body color dark brown from dorsum to pectoral fin bases, sides with 14-17 vertical bars, each one or two scales wide, extending both dorsally and ventrally, sometimes united with dorsal transverse bars. Lateral stripe absent.

Pectoral fin with distal tips of first five rays dark brown, but not forming spots or bands. Ventral, anal, dorsal, and adipose fins hyaline. Caudal fin with middle rays dark brown to their tips, scales on basal half of lower lobe appearing as dark blotch on its center. Ventral part of body dark yellow, completely lacking chromatophores or spots.

Sexual dimorphism. Breeding tubercles found in all males examined, located from ventral part of snout to tip of supraoccipital process; in those above $100 \mathrm{~mm}$ SL tubercles also present on pectoral-fin bases. First two branched dorsal-fin rays longer than rest, especially notable in males over $75 \mathrm{~mm}$ SL in which these rays usually reach to adipose fin when depressed.

Distribution. Río Orinoco basin, in Colombia and Venezuela (Fig. 2).
Comments. Fowler (1943) proposed Nematoparodon as a subgenus of Parodon, with P. apolinari as type species of this monotypic unit, based primarily on the filamentous extensions of the first two branched dorsal-fin rays, and the larger number of nuptial tubercles. These characteristics according to Wiley \& Collette (1970), Géry (1977), and Zanata \& Vari (2005) are sexually dimorphic characters present in a few Characiformes and many Cypriniformes (Myers, 1930; Parenti, 1981). In this study we observed them only in adult, male specimens, especially those collected in February (INHS 34711; ICN 1032) which corresponds to the dry season. These characters do not warrant recognition of a distinct subgenus according to Pavanelli (2003) who also noted that P. apolinari shares its peculiar pigmentation pattern only with $P$. caliensis. Elongate dorsal-fin rays have also been observed in Cypriniformes (Myers, 1930; Géry, 1977) and the African family Alestidae (Zanata \& Vari, 2005). Zanata \& Vari (2005) also report the prolongation of the dorsal-fin rays from several alestid genera, notable among them Bryconaethiops Günther, possibly suggesting a phylogenetic relationship with Parodontidae.

Material examined. Colombia. CAS-SU 23725, holotype, 89.0 $\mathrm{mm}$ SL, Meta, Guaicaramo, Orinoco basin, río Meta drainage, at junction of río Guavio and río Upia, SU 40203, 3, 68.1-95.1 mm SL, same data as the holotype. IAvH 3438, 7, 72.6-88.7 mm SL, Meta, río Cravo Sur, río Túa/Unete drainage, 442’N 71³6’W. IAvH 7896, 10, 45.3-62.1 mm SL, Casanare, río Chiquito at bridge on VillaoYopal road, 56’35.6”N, 72³6’31.6”'W, 316 masl. IAvH 8640, 7, 56.4-72.5 mm SL, Casanare, Creek near entrance to CPF Cupiagua, Sogamoso road, 5’12'35.5'N 72³6’48'W, 440 masl. IAvH 9533, 6, 45.6-78.1 mm SL, Casanare, creek near entrance of CPF Cupiagua, Sogamoso road, 512’35.5’'N, 72³6'48’'W, 440 masl. IAvH 9534, 5, 55.9-100.4 mm SL, Casanare, La Aguatoca Creek at bridge on Morro road, 5²6'21.2'”N, 72²7'9.7'’ 3 , 357 masl. IAvH 9537, 2, 47.5-63.8 mm SL, Casanare, rio Túa, 454'30.6”N, 7253'33.1'W, 449 masl. IAvH 9542, 2, 43.7-46.4 mm SL, Casanare, rio Tocaría, $5^{\circ} 30^{\prime} 47^{\prime} ’ \mathrm{~N}$, $72^{\circ} 13$ ' 2'W, 310 masl. IAvH 9544, 3, 61.6-70.3 mm SL, Casanare, rio Túa at bridge on Villao-Yopal road, 453'8.7'N, 7254'17.2”W, 418 masl. IAvH 5517, 2, 70.3-73.2 mm SL, Meta, Sardinata Creek at Bocas, La Carmpa road, Puerto Caldas Inspectorate, $3^{\circ} 28^{\prime} 30.8^{\prime \prime} \mathrm{N}$, 7343'12'W. IAvH 5519, 2, 77.5-83.6 mm SL, Meta, rio Ariari at "Guillermo León Valencia" bridge, Puerto Caldas Inspectorate, 329'1.8”'N, 7343'15.8”'W. ICN 1032, 6, 65.7-89.8 mm, Meta, rio Meta/Casanare drainage, rio Ariporo at Paz de Ariporo. ICN 15734, 2, 56.6-61.1 mm SL, Meta, Acacias, rio Orotog, oil company bridge. ICN 12201, 1, 99.4 mm SL, Meta, rio Ariari, Villavicencio. ICN 3327 , 1, $66.4 \mathrm{~mm}$ SL, Meta, Cayaguara creek, Casanare, Aguazul. MCZ 32168, 1, 68.0 mm SL, Meta, Guaicamo. MCZ 47682, 2, 54.2-78.0 mm SL, Meta, "Probably from small streams of Sierra Azul, easternmost range of Andes". Venezuela, UF 45865, 49, 44.9-94.3 $\mathrm{mm}$ SL, Barinas, creek that runs into rio Paguey, $c a 6 \mathrm{~km}$ N of Hwy 5. UF 36144, 4, 45.7-59.1 mm SL, Portuguesa, Guanare $2 \mathrm{kms}$ from bridge on Guanare-Barinas Hwy. UF 80559, 1, 80.9 mm SL, Guarico, Parque Nacional Aguaro-Guariquito about $39 \mathrm{~km}$ SE of Palenque, tributaries of rio Agua Blanca (Cano Yagrumito). INHS 31807, 6, 47.9-97.4 mm SL, Barinas, Arenosa Creek (rio La Yuca/Masparro drainage) $14 \mathrm{~km} \mathrm{~N}$ of Barinas. INHS 34711, 5, 55.2-71.1 mm SL, Barinas, rio Curito (rio Suripa drainage) $8 \mathrm{~km} \mathrm{NE}$ of San Antonio on Hwy 5. INHS 34913, 2, 41.2 -75.3mm SL, Yaracuy, Caripial creek (rio Aroa drainage) $13 \mathrm{~km}$ SE of Yumare. INHS 59892, 1, $102.8 \mathrm{~mm}$ 
SL, Portuguesa, rio Are (rio Guache/Portuguesa drainage) Aparición, at Hwy 5 bridge. INHS 69488, $7+1$ c\&s, 32.6-42.2 mm SL, Guanare, rio Orinoco/Apure drainage, rio Guanare at bridge in Guanare.

\section{Parodon atratoensis, new species} Fig. 4

Parodon suborbitale.-Román-Valencia, 1990: 204 (listed as present in Atrato River basin).

Parodon suborbitalis.-Eigenmann, 1922: 109 (listed as present at Quibdó, Chocó department, and Truandó River, Atrato Basin). Maldonado et al., 2006:147 (listed as present in Atrato River basin, catalog numbers for Colombian collections)

Holotype. ICN 17100, 107.5 mm SL, Colombia, Chocó, Neguá, río Atrato drainage, upper río Neguá, $5^{\circ} 15^{\prime} \mathrm{N}, 76^{\circ} 49^{\prime} \mathrm{W}$, elevation 146 masl, 16 Dec 1987, C. Román-Valencia.

Paratypes. Colombia, ICN 1584, 1, $98.4 \mathrm{~mm}$ SL, collected with holotype. ICN 132, 2, 71.5-83.5 mm SL, Chocó, Quibdó, río Atrato drainage, 3 Aug 1959, G. Dahl. CAS 6781, 1, 93.6 mm SL, Chocó, río Sucio, río Atrato drainage, río Truando, a western tributary emptying into the Atrato near R. Sucio, 1 Jan 1913-31 Dec 1913, C. Wilson.

Diagnosis. Parodon atratoensis differs from all congeners in having just the first dorsal-fin ray unbranched ( $v s$. two, except in P. magdalenensis); two dorsal longitudinal stripes that end at adipose-fin origin ( $v s$. ending at upper caudal-fin lobe or absent). It is distinguished from P. magdalenensis by a series of transverse dorsal bands ending at adipose fin ( $v s$. ending at upper caudal-fin lobe or absent); in having the axillary scale 2-3 normal scales in length (vs. usually one, rarely two scales in length; except in P. buckleyi). It also differs in the number of cusps on the premaxillary teeth (12-13 vs. 15-19 in P. carrikeri; 7-12 in P. bifasciatus; 9-12 in P. pongoensis). It can be differentiated from $P$. guyanensis by the number of teeth on the premaxilla (4 vs. 5) and from $P$. pongoensis and $P$. moreirai by the presence of a lateral band with projections above and below (vs. absence of projections in such band) and the number of scales in the lateral line (37-38 vs. 40-42 in P. moreirai). From $P$. suborbitalis it is distinguished by the number of cusps on premaxillary teeth (12-13 vs. 15-17); number of branched pectoral-fin rays (12-13 vs. 14-17); preanal scales (23-24 vs. 24-27); two light dorsal stripes uniting at adipose fin ( $v s$. stripes ending at upper caudal-fin lobe) and transverse dorsal blotches ending at adipose fin (vs. dorsal blotches ending at base of upper caudal-fin lobe). From $P$. hilarii it differs by the absence of spots above lateral stripe (vs. present); the number of preanal scales (23-24 vs. 24-28). It differs from $P$. nasus by the presence of elongated projections of the lateral stripe ( $v s$. rounded projections) and the number of cusps on premaxillary teeth (12-13 vs. 13-15).

Description. Morphometric and meristic data given in Tables 1 and 2, respectively. Body stout. Dorsal head profile straight from snout to tip of supraoccipital process. Ventral head profile straight from snout to isthmus; isthmus located at vertical through tip of supraoccipital process. Dorsal trunk profile convex from tip of supraoccipital process to dorsal-fin origin, straight from there to upper caudal-fin lobe. Branchial membranes united to each other but free from isthmus. Eyes lateral; nares at height of eye, two orifices separated by projecting skin membrane, anterior orifice larger. Mouth ventral, upper lip absent. Ventral trunk profile rounded from isthmus to anal-fin origin, then concave to lower caudal-fin lobe. Caudal peduncle compressed.

Premaxillary hemiseries with four teeth in straight line, each tooth with straight ventral margin and 12-13 small cusps; these teeth fit into space in lower jaw. Maxilla with one or two multicuspid teeth, smaller than those on premaxilla and often half buried in soft tissue. Lower jaw with one to three lateral, outwardly-curved teeth, not visible when jaw closed.

Pectoral fin inserted at vertical through tip of supraoccipital process, or one scale posterior; fins short, their tips not reaching pelvic-fin insertions; fifth branched ray longest. Pelvic fin always reaching genital pore but not anal-fin origin even in adults; inserted at vertical through middle of dorsalfin base. Dorsal fin truncate, with second to fourth rays longer than others, its origin at or slightly posterior to vertical through point midway between pectoral and pelvic fin insertions. Anal fin not reaching lower caudal-fin lobe by one or two scales, its origin at vertical through point one or two

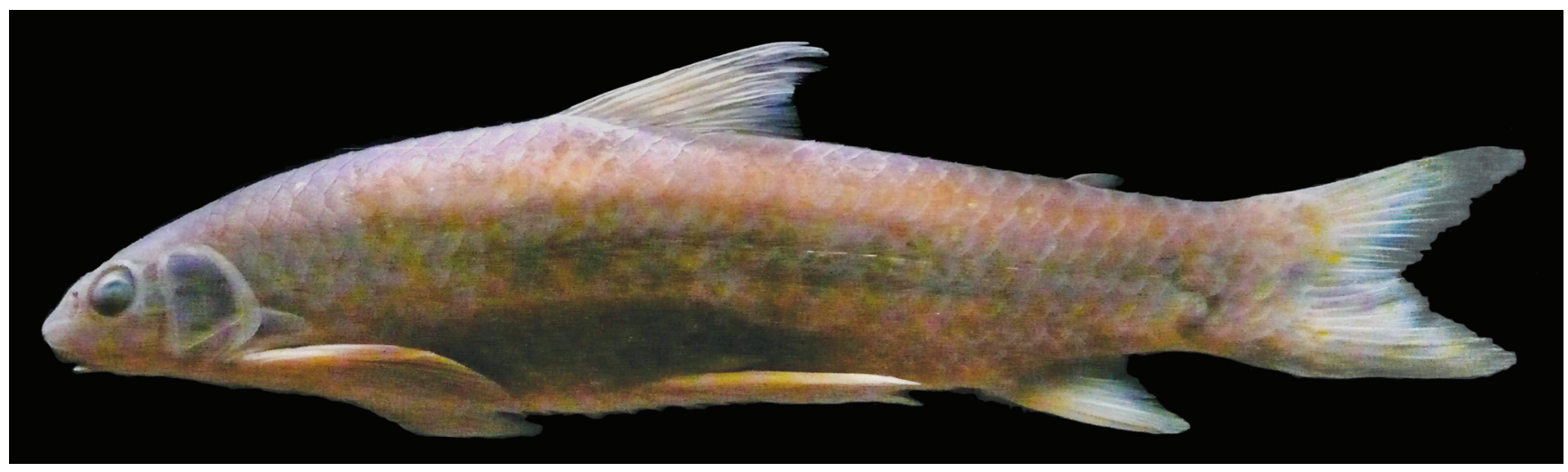

Fig. 4. Parodon atratoensis, Holotype, ICN 17100, 107.5 mm SL. Colombia, Atrato River system, upper Neguá River, Neguá, Chocó. 
Table 3. Morphological measurements as percent of SL and HL for Parodon apolinari $(\mathrm{n}=108)$, P. buckleyi $(\mathrm{n}=19)$, P. caliensis $(\mathrm{n}=22)$, and P. pongoensis $(\mathrm{n}=23)$. Hol. $=$ holotype, Lect. $=$ Lectotype. Standard and total length in $\mathrm{mm}$.

\begin{tabular}{|c|c|c|c|c|c|c|c|c|c|c|c|c|c|c|c|c|}
\hline & \multicolumn{4}{|c|}{ P. apolinari } & \multicolumn{4}{|c|}{ P. buckleyi } & \multicolumn{4}{|c|}{ P. caliensis } & \multicolumn{4}{|c|}{ P. pongoensis } \\
\hline & Hol. & Mean & Low & High & Hol. & Mean & Low & High & Lect. & Mean & Low & High & Hol. & Mean & Low & High \\
\hline Standard length & 89.0 & 68.4 & - & - & 111.4 & 93.9 & - & - & 57.0 & 66.4 & - & - & 62.0 & 51.6 & - & - \\
\hline Total length & 108.3 & 83.6 & - & - & 135.0 & 112.7 & - & - & 70.7 & 80.6 & - & - & 71.4 & 63.4 & - & - \\
\hline \multicolumn{17}{|c|}{ Percents of standard length } \\
\hline Body depth & 28.3 & 26.6 & 23.5 & 31.3 & 23.8 & 25.6 & 19.9 & 30.8 & 27.7 & 27.3 & 23.7 & 32.3 & 24.0 & 24.5 & 22.4 & 26.2 \\
\hline Caudal peduncle depth & 13.0 & 13.6 & 11.6 & 16.3 & 12.7 & 12.7 & 10.7 & 13.9 & 11.5 & 12.6 & 11.2 & 14.6 & 11.3 & 11.8 & 10.4 & 12.7 \\
\hline Anal fi & 19.4 & 18.0 & 13.7 & 22.6 & 19.0 & 16.8 & 11.9 & 20.0 & 14.8 & 15.3 & 14.2 & 16.3 & 14.1 & 15.7 & 13.8 & 17.6 \\
\hline length & 11.2 & 12.6 & 10.0 & 14.8 & 12.3 & 11.8 & 10.2 & 13.6 & 9.4 & 11.8 & 10.9 & 12.5 & 11.2 & 12.0 & 11.2 & 12.9 \\
\hline & 18.6 & 21.3 & 16.9 & 24.4 & 18.5 & 20.1 & 17.6 & 21.9 & 24.1 & 23.9 & 21.2 & 25.7 & 20.3 & 22.1 & 20.3 & 24.3 \\
\hline & 22.7 & 25.4 & 19.2 & 44.1 & 23.5 & 22.4 & 19.0 & 27.4 & 21.3 & 21.5 & 20.8 & 22.3 & 20.2 & 22.8 & 20.2 & 24.9 \\
\hline & 20.8 & 20.9 & 17.2 & 23.8 & 22.4 & 21.1 & 18.6 & 23.4 & 19.5 & 21.1 & 19.6 & 23.1 & 20.7 & 20.1 & 17.6 & 21.6 \\
\hline & 19.0 & 19.1 & 15.8 & 23.9 & 18.8 & 19.2 & 16.6 & 21.8 & 17.1 & 17.7 & 15.4 & 19.5 & 17.4 & 18.1 & 16.9 & 19.1 \\
\hline & 16.0 & 14.1 & 9.9 & 17.5 & 15.2 & 15.2 & 11.4 & 18.8 & 14.3 & 14.2 & 12.6 & 17.2 & 17.1 & 15.0 & 12.2 & 17.1 \\
\hline & 8.9 & 47.6 & 43.8 & 52.3 & 45.6 & 46.1 & 40.8 & 48.4 & 47.6 & 49.2 & 46.9 & 51.0 & 48.6 & 47.3 & 45.4 & 49.0 \\
\hline & 19.3 & 19.4 & 15.9 & 22.9 & 18.5 & 18.0 & 15.3 & 21.1 & 17.0 & 17.2 & 15.7 & 18.5 & 17.2 & 17.6 & 15.3 & 18.8 \\
\hline in hase & 31.5 & 30.0 & 26.5 & 35.6 & 29.8 & 29.7 & 25.9 & 31.3 & 23.1 & 29.0 & 26.9 & 32.5 & 25.9 & 28.0 & 25.9 & 29.6 \\
\hline Dors & 26.4 & 26.4 & 23.8 & 31.8 & 23.2 & 25.6 & 21.0 & 30.7 & 28.8 & 27.0 & 23.6 & 31.9 & 20.7 & 24.3 & 20.7 & 31.5 \\
\hline Dorsa & 33.1 & 30.2 & 26.5 & 36.0 & 32.4 & 29.8 & 26.2 & 31.5 & 32.6 & 30.8 & 28.7 & 33.1 & 31.2 & 28.1 & 26.4 & 31.2 \\
\hline Pecto & 35.2 & 33.6 & 30.4 & 39.9 & 32.2 & 32.4 & 28.6 & 35.5 & 32.3 & 33.5 & 31.2 & 36.5 & 32.5 & 31.1 & 28.8 & 32.5 \\
\hline Pect & 35.4 & 33.1 & 29.8 & 39.7 & 35.9 & 33.1 & 29.0 & 36.2 & 31.6 & 32.8 & 29.6 & 37.8 & 30.4 & 29.3 & 25.3 & 31.5 \\
\hline & 43.8 & 42.4 & 23.6 & 48.7 & 42.6 & 41.3 & 36.0 & 44.8 & 39.7 & 41.3 & 38.3 & 45.3 & 41.3 & 39.6 & 37.2 & 42.3 \\
\hline & 36.1 & 37.0 & 33.6 & 42.0 & 38.7 & 37.1 & 30.6 & 44.0 & 38.6 & 36.3 & 34.2 & 43.3 & 38.2 & 37.3 & 33.0 & 40.5 \\
\hline & 3.5 & 25.9 & 23.4 & 29.9 & 29.3 & 25.5 & 22.6 & 30.7 & 28.2 & 25.9 & 23.3 & 29.6 & 26.4 & 26.4 & 23.9 & 28.5 \\
\hline & 4.0 & 23.6 & 20.5 & 28.2 & 21.0 & 22.6 & 18.0 & 27.1 & 25.7 & 23.7 & 21.0 & 28.8 & 20.5 & 21.5 & 19.6 & 24.7 \\
\hline & 30.8 & 27.5 & 24.9 & 33.1 & 27.2 & 28.0 & 24.2 & 30.4 & 28.9 & 26.4 & 24.1 & 32.6 & 27.1 & 27.0 & 25.0 & 28.7 \\
\hline Isthmus to dorsal fin & 31.7 & 36.1 & 23.4 & 40.9 & 32.5 & 35.2 & 31.5 & 38.4 & 39.7 & 37.8 & 35.0 & 47.1 & 30.8 & 39.3 & 30.8 & 53.0 \\
\hline \multicolumn{17}{|c|}{ Percents of head length } \\
\hline & 7.5 & 39.1 & 24.1 & 44.6 & 33.6 & 39.6 & 34.7 & 42.2 & 28.1 & 33.7 & 25.1 & 38.0 & 31.2 & 32.8 & 29.1 & 39.4 \\
\hline & 23.4 & 24.5 & 19.4 & 43.5 & 23.9 & 22.4 & 18.2 & 26.6 & 24.6 & 24.2 & 21.1 & 26.7 & 26.1 & 26.1 & 23.6 & 28.6 \\
\hline & 42.2 & 39.0 & 32.8 & 45.6 & 34.3 & 38.6 & 33.6 & 47.0 & 41.1 & 44.4 & 38.3 & 48.5 & 51.4 & 45.2 & 38.2 & 51.4 \\
\hline Snot & 36.0 & 34.2 & 25.7 & 38.5 & 30.9 & 35.3 & 31.8 & 41.1 & 24.7 & 26.6 & 20.6 & 29.8 & 23.1 & 27.6 & 23.1 & 34.3 \\
\hline Snou & 73.3 & 71.2 & 57.4 & 80.5 & 60.3 & 72.0 & 68.2 & 83.3 & 60.4 & 68.2 & 53.3 & 74.0 & 70.3 & 69.2 & 55.1 & 83.7 \\
\hline Snou & 76.1 & 85.9 & 74.4 & 96.0 & 67.3 & 87.2 & 82.3 & 94.1 & 56.2 & 75.5 & 54.5 & 88.1 & 74.9 & 80.8 & 71.3 & 93.4 \\
\hline Isthm & 44.1 & 33.8 & 27.4 & 47.5 & 38.9 & 33.7 & 30.6 & 36.5 & 23.9 & 33.5 & 30.5 & 36.9 & 36.4 & 38.8 & 32.3 & 45.2 \\
\hline $\begin{array}{l}\text { Tip of supraoccipital process to maxillary } \\
\text { commissure }\end{array}$ & 72.6 & 75.9 & 57.7 & 84.3 & 83.8 & 77.4 & 72.2 & 89.2 & 76.8 & 73.9 & 68.4 & 86.2 & 75.4 & 81.0 & 73.1 & 95.5 \\
\hline & 72.4 & 75.5 & 68.6 & 97.9 & 70.5 & 76.1 & 70.1 & 85.8 & 74.1 & 74.3 & 68.7 & 83.0 & 62.2 & 72.1 & 62.2 & 78.5 \\
\hline 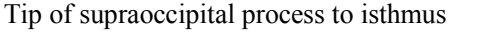 & 67.4 & 70.3 & 53.6 & 77.6 & 89.0 & 71.1 & 65.9 & 78.0 & 73.7 & 69.7 & 61.4 & 82.6 & 68.4 & 73.7 & 67.3 & 88.3 \\
\hline & 44.8 & 41.3 & 34.6 & 57.4 & 45.5 & 41.3 & 39.3 & 42.5 & 39.7 & 40.1 & 38.0 & 42.9 & 43.3 & 41.8 & 37.5 & 44.9 \\
\hline Lower jaw length & 35.3 & 27.1 & 20.5 & 35.3 & 26.1 & 26.1 & 23.2 & 29.3 & 20.0 & 20.7 & 18.5 & 22.3 & 24.0 & 22.9 & 19.1 & 27.6 \\
\hline
\end{tabular}

Table 4. Counts for Parodon apolinari $(\mathrm{n}=108)$, P. buckleyi $(\mathrm{n}=20)$, P. caliensis $(\mathrm{n}=27)$, and P. pongoensis $(\mathrm{n}=24)$.

\begin{tabular}{|c|c|c|c|c|c|c|c|c|c|c|c|c|}
\hline & \multicolumn{3}{|c|}{ P. apolinari } & \multicolumn{3}{|c|}{ P. buckleyi } & \multicolumn{3}{|c|}{ P. caliensis } & \multicolumn{3}{|c|}{ P. pongoensis } \\
\hline & Low & High & Holotype & Low & High & Holotype & Low & High & Lectotype & Low & High & Holotype \\
\hline Premaxillary teeth cusps & 14 & 26 & - & 16 & 22 & - & 13 & 15 & - & 9 & 12 & - \\
\hline Maxillary teeth & 1 & 2 & 2 & 2 & 2 & - & 1 & 2 & 2 & 1 & 2 & 1 \\
\hline Premaxillary teeth & 4 & 4 & 4 & 4 & 4 & - & 4 & 5 & 4 & 4 & 4 & 4 \\
\hline Lower jaw teeth & 1 & 3 & - & 3 & 4 & - & 1 & 2 & - & 1 & 3 & - \\
\hline Circumpeduncular scales & 16 & 16 & 16 & 16 & 16 & 16 & 15 & 16 & 16 & 16 & 16 & 16 \\
\hline Lateral line scales & 35 & 38 & 37 & 39 & 40 & 39 & 39 & 40 & 40 & 34 & 38 & 38 \\
\hline Scales between dorsal fin and adipose fin & 10 & 13 & 12 & 12 & 14 & 14 & 11 & 14 & 14 & 10 & 13 & 13 \\
\hline Post-adipose scales & 5 & 8 & 6 & 7 & 8 & 7 & 6 & 8 & 7 & 6 & 8 & 8 \\
\hline Post-anal scales & 2 & 4 & 3 & 4 & 5 & 4 & 1 & 2 & 2 & 2 & 3 & 3 \\
\hline Preanal scales & 22 & 27 & 24 & 24 & 27 & 27 & 26 & 29 & - & 22 & 26 & 26 \\
\hline Predorsal scales & 10 & 12 & 12 & 12 & 13 & 13 & 12 & 15 & 14 & 11 & 13 & 13 \\
\hline Rows of scales below the lateral line & 4 & 4 & 4 & 4 & 4 & 4 & 4 & 5 & 4,5 & 3 & 4 & 4 \\
\hline Rows of scales above the lateral line & 4 & 4 & 4 & 4 & 4 & 4 & 4 & 5 & 5 & 4 & 5 & 4 \\
\hline Anal fin rays & $\mathrm{i}, 7$ & $\mathrm{I}, 8$ & - & $\mathrm{i}, 7$ & $\mathrm{i}, 7$ & - & $\mathrm{i}, 6$ & $\mathrm{i}, 7$ & - & $\mathrm{i}, 7$ & $\mathrm{i}, 8$ & - \\
\hline Caudal fin rays & $\mathrm{i}, 17, \mathrm{i}$ & $\mathrm{i}, 17, \mathrm{i}$ & - & $\mathrm{i}, 17, \mathrm{i}$ & $\mathrm{i}, 17, \mathrm{i}$ & - & $\mathrm{i}, 17, \mathrm{i}$ & $\mathrm{i}, 17, \mathrm{i}$ & - & $\mathrm{i}, 17, \mathrm{i}$ & $\mathrm{i}, 17, \mathrm{i}$ & - \\
\hline Dorsal fin rays & ii,9 & Ii, 10 & - & ii, 10 & ii, 10 & - & ii,9 & ii, 10 & - & $\mathrm{ii}, 8$ & $\mathrm{ii}, 10$ & - \\
\hline Pectoral fin rays & $\mathrm{i}, 14$ & $\mathrm{i}, 16$ & - & $\mathrm{i}, 13$ & $\mathrm{i}, 15$ & - & $\mathrm{i}, 12$ & $\mathrm{i}, 13$ & - & $\mathrm{i}, 11$ & $\mathrm{i}, 14$ & - \\
\hline Pelvic fin rays & $\mathrm{i}, 7$ & $\mathrm{I}, 7$ & - & $\mathrm{i}, 7$ & $\mathrm{i}, 7$ & - & $\mathrm{i}, 7$ & $\mathrm{i}, 7$ & - & $\mathrm{i}, 7$ & $\mathrm{i}, 7$ & - \\
\hline
\end{tabular}


scales anterior to adipose-fin origin. Adipose fin not reaching upper caudal-fin lobe, its origin at vertical through middle of anal-fin base. Caudal fin with two lobes of equal length, covered proximally with scales for $1 / 3$ length. Lateral line with 37-38 pored scales, complete, extending on to proximal third of caudal fin. Predorsal and ventral regions regularly scaled. Axillary scale present, two to three scales in length.

Color in alcohol. Snout and head usually uniformly brown, not lighter below eye (one $98.4 \mathrm{~mm}$ SL individual with lighter colored infraorbitals two and three). Dorsum of body with series of light brown transverse blotches that begin one scale posterior to tip of supraoccipital process and continue to adipose-fin base, delimited on both sides of body by two light brown stripes of at least two scales in width, that begin on snout or behind supraoccipital and extend posteriorly to unite at adipose fin. Body base color dark yellow. Dark lateral stripe zigzag with 13-15 very short points, most conspicuous in individuals smaller than $85 \mathrm{~mm}$ SL; no additional blotches or bands observed above zigzag stripe. Lateral stripe continued onto middle caudal-fin rays.

Pectoral fin with light brown blotch usually distal in position but sometimes larger, extending towards base of fin, all rays with very disperse brown chromatophores, giving fin very dark general appearance. Pelvic fin with very few chromatophores not forming blotches or bands. Anal and adipose fins hyaline. Dorsal fin with first four rays covered with dark brown chromatophores not forming blotches or bands. Caudal fin with middle rays dark brown to tips. Ventral part of body same as base color of sides, without spots or chromatophores.

Sexual dimorphism. Few breeding tubercles observed in males, usually only on anterior part of snout. In one male, $107.5 \mathrm{~mm}$ SL tubercles present from snout to supraoccipital.

Distribution. Río Atrato basin, Colombia (Fig. 2).

Etymology. This species, Parodon atratoensis, is named in reference to its type-locality, the Atrato River, northwest Colombia.

Comments. Román-Valencia (1990) reported Parodon suborbitalis from the Atrato River drainage. In this study, we re-examined two specimens he used (ICN 1584) and confirm that they are the new species described here as P. atratoensis. They are distinguished from $P$. suborbitalis by the following characters: number of cusps on premaxillary teeth: 12-13 (vs. 15-17); number of branched pectoral-fin rays 12-13 (vs. 1416); one simple dorsal-fin ray ( $v s$. two); preanal scales 23-24 (vs. 24-27); spots above lateral stripe absent (vs. present); two light dorsal stripes uniting at adipose fin ( $v s$. stripes ending at upper caudal-fin lobe) and transverse dorsal blotches ending at adipose fin ( $v s$. dorsal blotches ending at base of upper caudal-fin lobe). Parodon suborbitalis is found in the Lake Maracaibo and is absent from Pacific Colombian coastal drainages. Reports of $P$. suborbitalis by Eigenmann
(1922) and Maldonado et al. (2005; 2006) from the Atrato were also based on specimens of $P$. atratoensis.

Parodon atratoensis shows little overlap in meristic characters with $P$. suborbitalis, so even though our sample size is small have found supporting evidence for us to diagnose those specimens as a new species, the only valid parodontid species known to date from the Atrato River drainage.

\section{Parodon buckleyi Boulenger, 1887 Figs. 5-6}

Parodon buckleyi Boulenger, 1887: 279 (type locality Canelos, Ecuador, $1^{\circ} 35^{\prime} \mathrm{N} 77^{\circ} 44^{\prime} \mathrm{W}$, elevation 456 masl; original description; meristic data tables, Holotype: BMNH 1880.12.5.125). Böhlke, 1958: 83 (description; synonymy with $P$. suborbitalis; tables with counts and measurements; lateral view photo). Géry, 1977: 202 (diagnosis in key). Ortega \& Vari, 1986: 11 (distribution in Peru). Pavanelli, 2003: 48 (distribution; localization of type material; maximum size, common names).

Diagnosis. Parodon buckleyi differs from all congeners in having (in adults) 3-4 dark lateral spots anterior to dorsal fin origin that unite across dorsum with spots from opposite side (vs. spots not dorsally united), juveniles have rounded or elongated dark lateral blotches, that are divided in two, not continuous (vs. dark spots of juveniles elongate and always continuous, except in P. nasus); by the greater number of cusps on the premaxillary teeth (16-22 vs. fewer than 17, except in $P$. apolinari and $P$. suborbitalis that have 14-26 and 15-17, respectively); higher pored lateral-line scales (39-40 vs. 38 or fewer, except in P. caliensis with 39-40); more post-anal scales (4-5 vs. 4 or fewer); longer axillary scale (three scales in length vs. 1-2). Parodon buckleyi can be distinguished by its greater caudal peduncle depth (10.7- $13.9 \%$ vs. $13.3-16.3 \%$ in P. alfonsoi and $12.2-16.1 \%$ in P. magdalenensis); by the number of cusps in premaxillary teeth (16-22 vs. 7-12 in P. bifasciatus; 9-12 in $P$. pongoensis). It differs from $P$. guyanensis by the number of teeth on the premaxilla (4vs. 5); from $P$. pongoensis and $P$. moreirai by the presence of a lateral band with projections above and below (vs. absence of projections in such band); from $P$. moreirai by the number of scales in the lateral line (3940 vs. 40-42); and normal sized teeth in the maxilla (vs. minute or absence of teeth). It can be distinguished from P. carrikeri by the number of scales in the lateral line (39-40 vs. 38-39), and the dark coloration along the body including most of the head ( $v s$. ground and general color of body, light not dark in P. buckleyi); and from $P$. hilarii by the high number of scales on the lateral line (39-40 vs. 37-39) and the higher number of cusps in premaxillary teeth (16-22 vs.11- 16; 13-15 in P. nasus).

Description. Morphometric and meristic data given in Tables 3 and 4, respectively. Body stout. Dorsal head profile straight from snout to tip of supraoccipital process. Ventral head profile straight from snout to isthmus. Isthmus located at vertical 


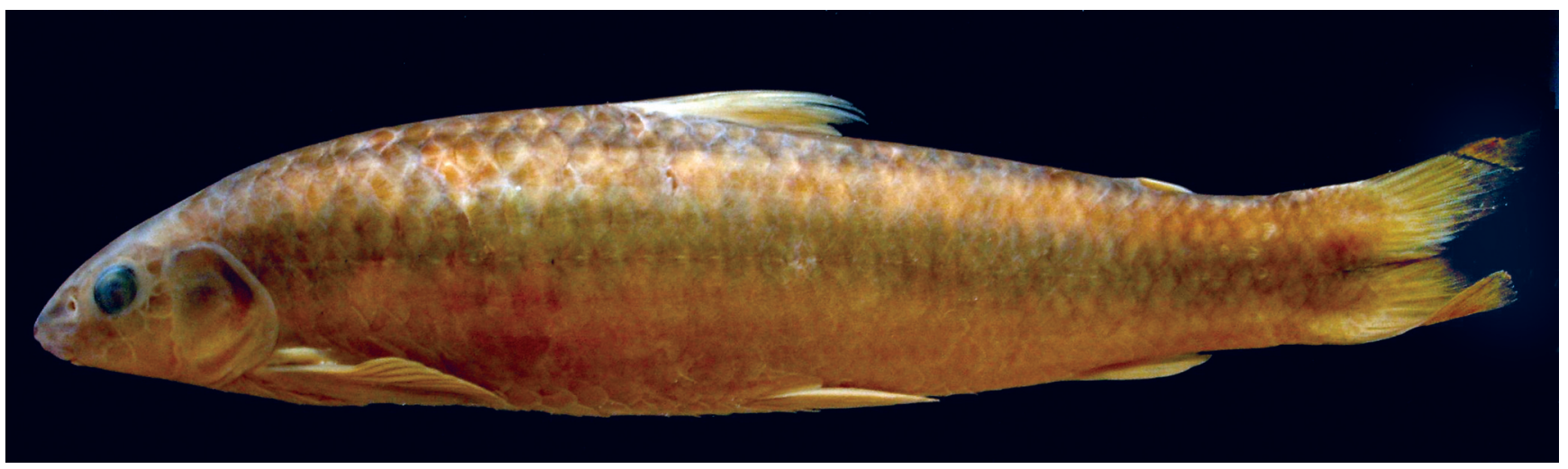

Fig. 5. Parodon buckleyi, IUQ 977, 131.2 mm SL, Colombia, Inchiyaco River above Villa Garzón-San José del Fragua road, Caquetá.

through tip of supraoccipital process. Dorsal trunk profile convex from tip of supraoccipital process to dorsal-fin origin, straight from there to caudal fin. Branchial membranes united to each other, free from isthmus. Eyes lateral; nares at level of eye, separated by projecting membrane of skin. Mouth ventral, upper lip absent. Ventral body profile straight from isthmus to caudal fin. Caudal peduncle compressed.

Premaxillary hemiseries with four teeth in straight line that have straight ventral margins and 16-22 small cusps that fit into space in lower jaw. Maxillary with 1-2 teeth. Lower jaw with three unicuspid, outwardly curved lateral teeth half covered with soft tissue and not visible when jaw closed.

Pectoral fin short, not reaching pelvic-fin insertions. Pectoral insertions at vertical through one scale posterior to tip of supraoccipital process, truncate in shape, with fourth branched ray longest. Pelvic fin not reaching anal-fin origin, and only in individuals less than $95 \mathrm{~mm}$ SL reaching genital pore, but not surpassing it. Pelvic fin located at vertical through middle of dorsal-fin base. Dorsal fin truncate located at vertical through midpoint between pectoral and pelvic fin insertions; first and second branched rays longest. Anal fin falls two scales short of lower caudal-fin lobe. Anal fin located at vertical through point three scales anterior to adipose fin. Adipose fin not reaching caudal fin, located at vertical through posterior margin of anal-fin base; caudal fin with upper lobe longer than lower. Proximal third of caudal fin covered with scales.

Lateral line with 39-40 pored scales that extend on to scaled portion of caudal fin. Scales regularly distributed in predorsal and ventral areas. Axillary scale present, three normal scales in length.

Color in alcohol. Body and head dark brown dorsally, lighter in color below horizontal line that passes below nares and eye. Dorsum with series of 8-10 brown transverse bands that begin near tip of supraoccipital process or two scales posterior to it, and continue to upper caudal-fin lobe, bands three scale widths long and one scale wide, and delimited by two dorsal longitudinal stripes of one half scale in width that originate at tip of supraoccipital process and continue posteriorly to unite with band of opposite side at upper caudal-fin lobe.

Base color of body dark brown, darker than that of congeners, especially in adults (except $P$. carrikeri and $P$. magdalenensis). Lateral stripe with 14 dorsal and ventral projections forming zigzag, but projections only easily visible in smaller specimens less than $85 \mathrm{~mm} \mathrm{SL}$, in which projections rounded or elongated but divided in two not complete as observed in other species with projections from lateral stripe. Above this stripe dorsal projections of anterior portion (to just before dorsal-fin origin) unite with dark bands of dorsum, forming continuous band from one side to other (in specimens greater than $66.3 \mathrm{~mm} \mathrm{SL}$ ) (Fig. 6). Lateral band extending to tips of middle caudal-fin rays. Distal most part of pectoral fins with few, disperse chromatophores (black in one specimen $81.6 \mathrm{~mm}$ SL). Pelvic, anal and adipose fin hyaline. Dorsal fin with first five rays dark, diffuse black, but not forming distinct spot or band. Caudal fin with middle rays dark brown to tips; no disperse chromatophores present on rest of fin. Ventral part of body of same base color but lighter than rest of body, no spots.

Sexual dimorphism. Breeding tubercles observed in males from lower part of snout to tip of supraoccipital process, easily visible and numerous.

Distribution. Middle Amazonas, Caquetá River drainage in Colombia; upper Amazonas in Ecuador, Peru and Bolivia (Fig. 2).

Comments. Fowler's (1945a) records of P. suborbitalis from the Morelia River (which is part of the Caquetá River system), for which he gave the following counts: "Scales 32 to $35+3$ in lateral line; 13 or 14 predorsal”, are P. buckleyi.

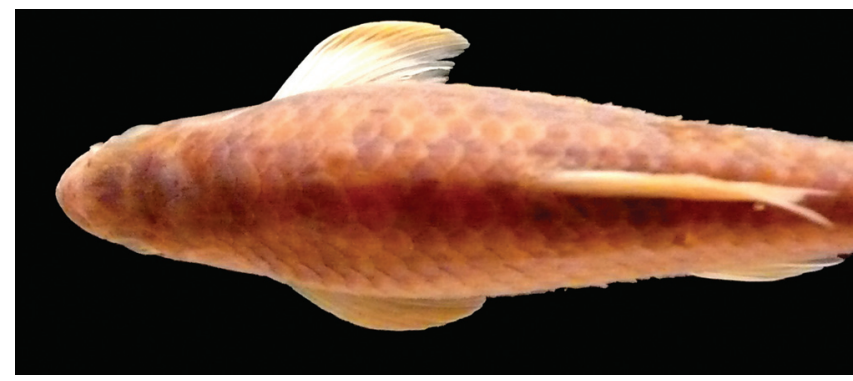

Fig. 6. Dorsal view of Parodon buckleyi, AMNH 233262, 66.3 $\mathrm{mm}$ SL, showing diagnostic pigmentation pattern of predorsal region. 
Böhlke (1958) used the number of cusps on premaxillary teeth to identify $P$. buckleyi which coincides with the original description by Boulenger (1887) but stated that it might not be distinct from P. suborbitalis Valenciennes of the Maracaibo basin. But we have found ample differences in color pattern and meristics (see above). According to Pavanelli (2003) this species is present in Ecuador, Peru, Brazil and Bolivia in upper Amazon tributaries. Specimens examined from upper Amazon tributaries of Bolivia and Peru coincide with ours from the Caquetá River in Colombia (middle Amazon basin). We thus report $P$. buckleyi as a new record for Colombia and note its presence in upper and middle Amazon tributaries from Colombia through Bolivia.

Material examined. Ecuador. BMNH 1880.12.8.125, 1, holotype, $111.4 \mathrm{~mm}$ SL, upper Amazon, río Canelos, east Ecuador, $1^{\circ} 35^{\prime} \mathrm{N}$ $77^{\circ} 44^{\prime} \mathrm{W}$, elevation 456 masl. Colombia. IUQ 1055, 1, $81.6 \mathrm{~mm}$ SL, Caquetá, río Fragua. ICN 5481, 2, 80.4-97.4 mm SL, Caquetá, Rumiyaco creek, río Inchiyaco drainage, upper Caquetá. IUQ 977, 2, 108.9-131.2 mm SL, Caquetá, río Inchiyaco, Villa Garzón-San José del Fragua road. Perú. ZMUC 24991, 1, 94.9 mm SL, upper Amazon, Las Pavas creek. Bolivia. AMNH 233262, 1, $66.3 \mathrm{~mm}$ SL, Santa Cruz, Ichilo Province, Amboro National Park, río La Chonta, La Chonta camp, 17³9'52”S, 6342’28”W. AMNH 233263, 1, 66.9 $\mathrm{mm}$ SL, Santa Cruz, Ichilo Province, Amboro National Park, río La Chonta, La Chonta camp, 17³9'52'S, 6442'28'W. AMNH 233303 , 1, 99.8 mm SL, Santa Cruz, Ichilo Province, Amboro National Park, río Macunucu, Macunucu camp, 1744'72’S, 63³6’47’W. UF 38169, 2, 62.0-66.2 mm SL, Cochabamba, Chapare Province, río Espíritu (río Chapare-Mamoré), brook at Villa Tunari, elevation 350 masl. UMMZ 66507, 8, 53.8-87.6 mm SL, La Paz, Tumupasa (village $30 \mathrm{mi} \mathrm{NW}$ of Rurrenabaque); Amazon drainage.

\section{Parodon caliensis Boulenger, 1895 Fig. 7}

Parodon caliensis Boulenger, 1895: 480 (type locality: río Cali, río Cauca drainage, Colombia, $3^{\circ} 27^{\prime} \mathrm{N} 76^{\circ} 32^{\prime} \mathrm{W}$, elevation 975 masl, Lectotype: BMNH 1895.11.16.83 designated by Londoño-Burbano \& Román-Valencia, 2010: 817). Eigenmann, 1922: 108-109 (key; meristic and morphometric data; distribution; lateral view illustration is of Saccodon dariensis). Miles, 1943: 42 (description; distribution; scale counts). Miles, 1947: 131-132 (key; distribution; lateral line scale counts, maximum size). Roberts, 1974b: 424-434; 469 (relationships with Hemiodontidae; illustration of jaws). Géry, 1977: 203 (key; scale counts; type locality). Pavanelli, 2003: 46-47 (synonymy; distribution; location of syntypes; maximum size, common names). Maldonado et al., 2005: 38; 255; 301 (lateral view illustration is of Saccodon dariensis; synonymy; common names; conservation status; description; ecology; distribution; museum records). Londoño-Burbano \& Román-Valencia, 2010: 814-819 (redescription; assignation of type series).

Parodon caliense.-Dahl, 1971: 117 (key; distribution; maximum size; figure is $S$. dariensis).
Parodon medellinense Posada, 1909: 299 (type locality: Medellin, Colombia. Holotype not assigned). Pavanelli, 2003: 46-47 (synonymy with P. caliensis). Maldonado et al. 2005: 38; 255; 301 (synonymy with $P$. caliensis following Pavanelli, 2003).

Diagnosis. Parodon caliensis differs from all congeners in having 6-8 vertical bars, each 2-3 scales wide on the sides, without a continuous lateral stripe ( $v s$. presence of lateral stripe, except in P. apolinari which has 14-17 vertical bars); and in having all fins, except the caudal, hyaline (vs. fins with chromatophores; see also Londoño-Burbano \& Román-Valencia, 2010).

Description. Morphometric and meristic data given in Tables 3 and 4, respectively. Body stout. Dorsal head profile straight from anterior part of snout to posterior margin of supraoccipital. Ventral profile of head straight from snout to vertical through anterior margin of third infraorbital thence rounded to posterior margin of isthmus. Dorsal trunk profile convex from posterior margin of supraoccipital to dorsal-fin origin, then straight to adipose fin, from there concave to caudal fin. Isthmus located at vertical through anterior part of opercle. Branchial membranes united to each other but not to isthmus. Eyes lateral; nares at height of eye; without projecting flap of skin dividing orifice in two, round in shape. Mouth ventral, upper lip absent. Ventral profile of trunk rounded from isthmus to anal fin then straight to caudal fin. Caudal peduncle compressed.

Premaxillary hemiseries with four teeth that fit into space in lower jaw (one specimen, $103.2 \mathrm{~mm} \mathrm{SL}$, with five teeth on left side, FMNH 56305), straight inferior margin of teeth with 13-15 small cusps. Lower jaw with 1-3 unicuspid, lateral, outwardly curved teeth, not visible when mouth closed. Maxilla with 1-2 multicuspid teeth smaller than those of premaxilla and half covered by surrounding soft tissue.

Pectoral fin short, not reaching pelvic fin or vertical through dorsal-fin origin; inserted at vertical through one scale behind tip of supraoccipital process; truncate with fourth and fifth rays longer than rest. Pelvic fin fall short of genital pore by two or three scales and inserted at vertical through posterior margin of dorsal-fin base, or one scale anterior to it. Pelvic fin truncate with first and second branched rays longest. Anal fin truncate, not reaching caudal fin; origin at vertical through second or third scale anterior to adipose-fin origin, first and second branched rays longest. Dorsal fin truncate, first and second branched rays longest, origin at vertical through midpoint between pectoral and pelvic-fin insertions or slightly posterior, falling short of adipose fin by more than six scales. Adipose-fin origin at vertical through posterior portion of anal fin. Two caudal lobes equal sized, middle rays light brown to tips, basal third covered with scales.

Lateral line with 39-40 pored scales that sometimes extend out on to scaled portion of fin. Predorsal and ventral regions with regularly arranged scales. Axillary scale present, one or two scales normal in length (see also Londoño-Burbano \& Román-Valencia, 2010). 


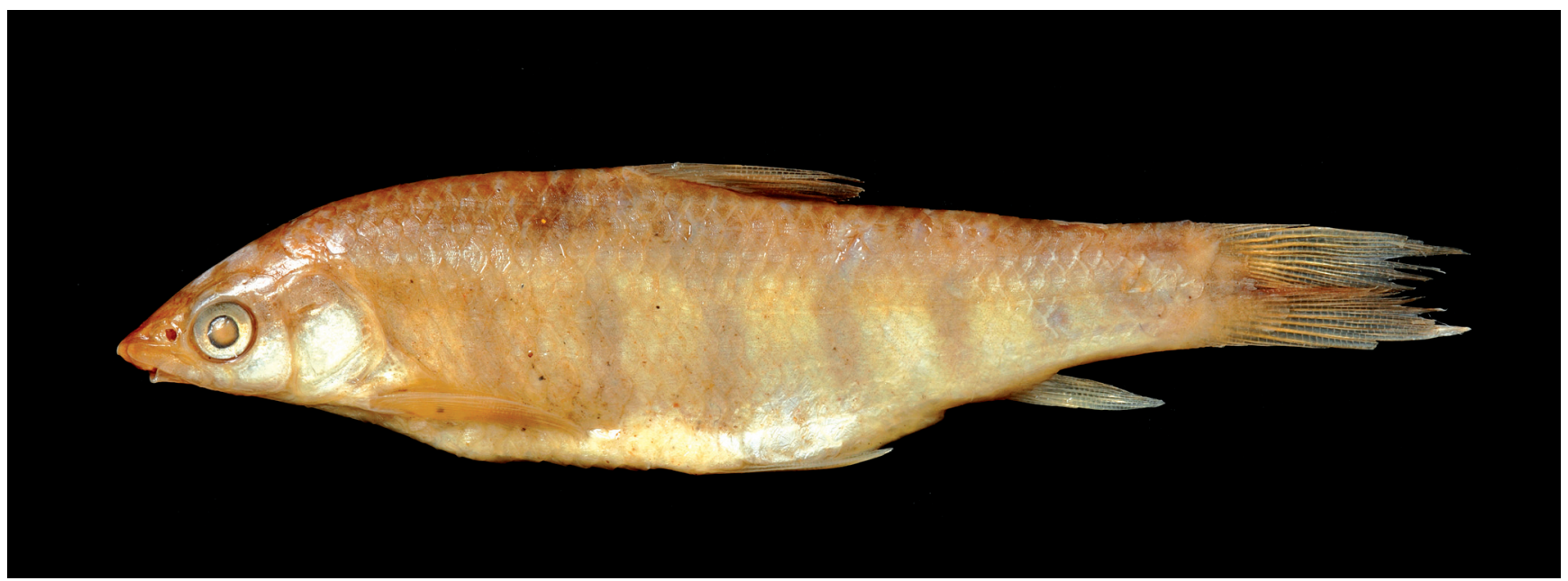

Fig. 7. Parodon caliensis, Lectotype, BMNH 1895.11.16.83, $57 \mathrm{~mm}$ SL, Colombia, Cali River, tributary of Cauca River (photo by James Maclaine, BMNH).

Color in alcohol. Dorsal part of snout and head brown, lighter below horizontal through middle of eye. Dorsum of body with series of 8-10 light brown transverse bars, separated by pale yellow or whitish spaces, beginning at tip of supraoccipital process, ending at caudal fin. Head above eye lighter than dorsum of body. Head below eye whitish, with few melanophores. Body with same color pattern as head, darker above lateral line.

Sides of body with 6-8 brown vertical bars, $2-3$ scales in width, touching dark part of dorsum above and extending down to within two scales above pelvic fin insertions, bars sometimes divided to form two vertically elongate spots.

All fins hyaline except caudal fin; its middle rays brown to their tips. Ventral portion of body lighter than rest, with few chromatophores (see also Londoño-Burbano \& RománValencia, 2010).

Sexual dimorphism. Breeding tubercles present only in males greater than $100 \mathrm{~mm}$ SL, very small and few in number, more numerous tubercles found posterior and lateral to supraoccipital process (see also Londoño-Burbano \& Román-Valencia, 2010).

Distribution. Occurs in the upper Cauca River drainage, Colombia (Fig. 2).

Comments. In the original description Boulenger (1895) did not designate a type series, nor indicate in which museum the specimens used to describe $P$. caliensis were deposited. However, images (photographs and $\mathrm{x}$-rays) of the syntypes (James Maclaine, e-mail February $4^{\text {th }}, 2008$; Pavanelli, 2003) were obtained for examination (see material and methods). Those specimens are cited as syntypes by Pavanelli (2003) and Eschmeyer (2010), and according to them these specimens were assumed as the series for the type designation. This series was used to designate a lectotype by Londoño-Burbano \& Román-Valencia (2010), and were assumed as the type series of the species in this study (see reference for designation).

According to Eigenmann (1922), Miles (1943; 1947), Dahl (1971), Mojica et al. (2002), and Maldonado et al. (2005), Parodon caliensis is found in the Magdalena River basin, and in illustrations presented by these authors, a fish with a color pattern typical of Saccodon dariensis (Meek \& Hildebrand) is shown (round separate spots in three rows along sides of body). This has led to a great deal of confusion with respect to these two species and their taxonomic identity. As noted above, the distribution of $P$. caliensis is limited to the upper Cauca River, whereas $S$. dariensis is found in several tributaries of the Magdalena and Cauca Rivers, as well as in parts of Panama and the Rancheria River of the Caribbean coastal Guajira region of Colombia. Parodon caliensis differs from Saccodon dariensis in having: only one unbranched pectoral-fin ray ( $v s$. two); teeth present on the sides of the lower jaw (vs. absent); color pattern of vertical brown bars and no horizontal stripe ( $v s$. separated, transversally elongate black spots arranged in three rows along sides of body); and higher number of circumpeduncular scales (16 vs. 12). For this reason we believe that specimens identified as $P$. caliensis by previous authors from the Magdalena River drainage are actually $S$. dariensis (see also Londoño-Burbano \& RománValencia, 2010 for further comments).

Posada (1909) described the species Parodon medellinense from Medellin, Colombia without citing a specific river. The author did not assign types or deposit material in any museum, making comparison with the Magdalena basin material examined here impossible, and since the type locality is the city of Medellin it is not possible to collect new material there. Pavanelli (2003) and Maldonado et al. (2005) reported $P$. medellinense as a synonym of $P$. caliensis. Our sampling indicates that $P$. caliensis is not present in the lower Cauca River near Medellin (type locality of P. medellinense). Posada's description did not contain any kind of illustration and his color description of the species matches the characteristics of a Saccodon species (see 
Discussion for further comments). Thus, due to the impossibility of studying material belonging to the type locality of $P$. medellinense and to unequivocally assign this species to either Parodon or Saccodon, we here maintain the synonymy of Parodon medellinense with $P$. caliensis proposed by Pavanelli, while noting that it could just as easily be interpreted as a synonym of Saccodon dariensis.

Material examined. Colombia. río Cauca basin: BMNH 1895.11.16.83, lectotype of Parodon caliensis, $57.0 \mathrm{~mm} \mathrm{SL}$, and BMNH 1895.11.16.84-87, 4 paralectotypes, 48.0-59.0 mm SL, Valle del Cauca, río Cali, $3^{\circ} 27^{\prime} \mathrm{N}, 7^{\circ} 32^{\prime} \mathrm{W}, 975$ masl. CAS 6779, 5, 48.2-56.0 mm SL, Valle del Cauca, Cali, río Cauca, 1009 masl. CAS 6780, 3, 82.2-89.5 mm SL, Valle del Cauca, Cartago, río Vieja, six miles from río Cauca, 918 masl. AMNH 7110, 2, 60.5-65.0 mm SL, Valle del Cauca, Cali, río Cauca, $3^{\circ} 27^{\prime} \mathrm{N}, 76^{\circ} 32^{\prime} \mathrm{W}, 975$ masl. FMNH 69790, 6, 53.2-62.0 mm SL, Valle del Cauca, Cali, río Cauca at Cali. FMNH 56305, 4, 83.1-103.2 mm SL, Valle del Cauca, Cartago, río La Vieja. MCZ 35893, 2, 50.4-58.1 mm SL, Valle del Cauca, Cali, río Cauca and tributaries.

\section{Parodon magdalenensis, new species Fig. 8}

Parodon suborbitale.-Miles, 1943: 132 (key; distribution; synonymy). Dahl, 1971: 116 (key; illustration in lateral view, distribution, comments).

Parodon suborbitalis.-Eigenmann, 1922: 108-109 (key; synonymy; distribution; lateral view illustration). Fowler, 1945b:2 (record from Tolima Department, Colombia). Maldonado et al., 2005: 39; 255; 301 (lateral view illustration, synonymy, common names, conservation status, description, biology, distribution, comments, museum records).

Parodon caliensis.-Cardona et al., 1998: 11-24 (presence in Cauca River basin).

Holotype. ICN 17099, 108.6 mm SL, Colombia, Caldas, Norcasia, middle río Magdalena drainage, río La Miel at escape tunnel, río Magdalena, 5³4'N, 7453'W, elevation 720 masl, 26 Mar 2006, P. Sánchez \& L. M. Mesa.

Paratypes. Colombia. ICN 16089, 6, 59.7-106.9 mm SL, collected with holotype. IUQ 2547, 2 c\&s, 73.2-100.1 mm SL, collected with holotype. IUQ 2221, 7, 45.0-65.2 mm SL, and IUQ 2385, 1 c\&s, 60.4 mm SL, Caldas, Samaná, middle río Magdalena drainage, río La Miel at confluence with río Tasajos, $5^{\circ} 24^{\prime} \mathrm{N}, 74^{\circ} 59^{\prime} \mathrm{W}, 1416$ masl, 4 Sep 2006, U. Jaramillo. IUQ 2367, 1, 126.9 mm SL, Valle del Cauca, río Frío drainage, upper río Cauca, río Portugal de Piedras, lower section station $001,4^{\circ} 03^{\prime} \mathrm{N}, 76^{\circ} 18^{\prime} \mathrm{W}, 2$ Oct 2008 , J. Anderson \& M. Ramirez. IUQ 2376, 2, 108.4-114 mm SL, Valle del Cauca, río Frío drainage, upper Cauca, río Portugal de Piedras, lower section, $4^{\circ} 03^{\prime} \mathrm{N}, 76^{\circ} 18^{\prime} \mathrm{W}, 11$ Nov 2008 , H. M. Ramirez, \& A. Arcila. ICN 16272; 13 + 2 c\&s, 33.7-74.3 mm SL, Caldas, middle río Magdalena drainage, río Samaná, 5²4’N, 7459'W, 1416 masl, 1 May 2006, P. Sánchez \& L. M. Mesa. IUQ 1238, 1, 109.6 mm SL, Valle del Cauca, La Paila, upper Cauca, río La Paila $200 \mathrm{~m}$ below bridge on La Paila-Tulua highway, $4^{\circ} 19^{\prime} \mathrm{N}, 7^{\circ} 03^{\prime} \mathrm{W}, 937$ masl,
Mar 2000, C. Román-Valencia et al. IUQ 1683, 1, 49.7 mm SL, Valle del Cauca, Zarzal, upper Cauca, Las Cañas creek, tributary of río Cauca, road to Zarzal, $4^{\circ} 21^{\text {'N }}$, 7604'W, 6 Aug 2007, C. RománValencia, J. Vanegas-Rios, \& A. Londoño-Burbano. IUQ 568, 2, 53.4-85.4 mm SL, Valle del Cauca, upper Cauca, San Pablo Creek, 4²3’N, 7604'W, 13 Sep 1996, M. Cardona, \& J. L. Jimenez.

Non types. Colombia. ICN 11491, 25, 34.8-61.2 mm SL, Caldas, La Dorada, middle río Magdalena drainage, bridge on Honda-La Dorada road, río Guarino, 20 Feb 2005. ICN 2031, 3, 70.6-88.5 mm $\mathrm{SL}$, middle río Magdalena drainage, oil pipe road Colombia-Línea Base, San Juan de Bedout Creek, May 1992. IUQ 2225, 2, 45-47.8 $\mathrm{mm}$ SL, middle Magdalena drainage, overflow of Amaní Reservoir, border between Victoria and Samaná, 30 Nov 2007. IUQ 1051, 1, $57.0 \mathrm{~mm}$ SL, upper río Cauca drainage, río Chanco, tributary of río Cauca, Ansermanuevo, 17 Jun 2000.

Diagnosis. Parodon magdalenensis differs from all congeners by presenting a completely dark ground portion above black lateral stripe that lacks projections or spots extending dorsally, in adults (vs. base color white to yellow above lateral stripe which often has projections or spots extending dorsally); base color below lateral stripe to level of axillary scale gray ( $v s$. body below lateral stripe same color as base color of rest of body, usually white or yellow); adults with well defined black spot from middle of pectoral fin to its tip (not reaching base), absent in juveniles (vs. chromatophores present on pectoral fin not forming well-defined spot, nor bar and often present in juveniles); no dark brown spots on dorsal part of sides above lateral stripe ( $v s$. dark brown spots present); branched pectoralfin rays 11-14 (vs. 14-16; except $P$. buckleyi which has 13-15 branched pectoral rays). Parodon magdalenensis differs from $P$. bifasciatus by the higher number of cusps in premaxillary teeth (11-15 vs. 7-12) and the lower number of post-adipose scales (6-8 vs. 7-10, as well as from P. hilarii and P. nasus which have the same count as $P$. bifasciatus). It is differentiated from $P$. guyanensis by the number of teeth on the premaxilla (4 vs. 5) and can be distinguished from $P$. pongoensis and P. moreirai by the presence of a lateral band with projections above and below ( $v s$. absence of projections in such band) and the number of scales in the lateral line (35-38 vs. 40-42 in P. moreirai), and normal sized teeth in the maxilla ( $v s$. teeth minute or absent). It can be distinguished from most $P$. carrikeri by the number of scales in the lateral line (35-38 vs. 38-39), and the dark coloration along the body including most of the head (vs. ground and general color of body light in P. magdalenensis). It differs from P. suborbitalis by the lower number of cusps in premaxillary teeth (11-15vs. 15-17).

Description. Morphometric and meristic data given in Tables 1 and 2, respectively. Body stout. Dorsal profile of body convex from snout to dorsal-fin origin, then straight to four scales anterior of caudal-fin, then concave to caudal fin. Ventral profile of head straight from snout to isthmus; isthmus at vertical through anterior part of opercle; branchial membranes united to each other but not to isthmus. Eyes lateral; lateral groove present from tip of snout to anterior 


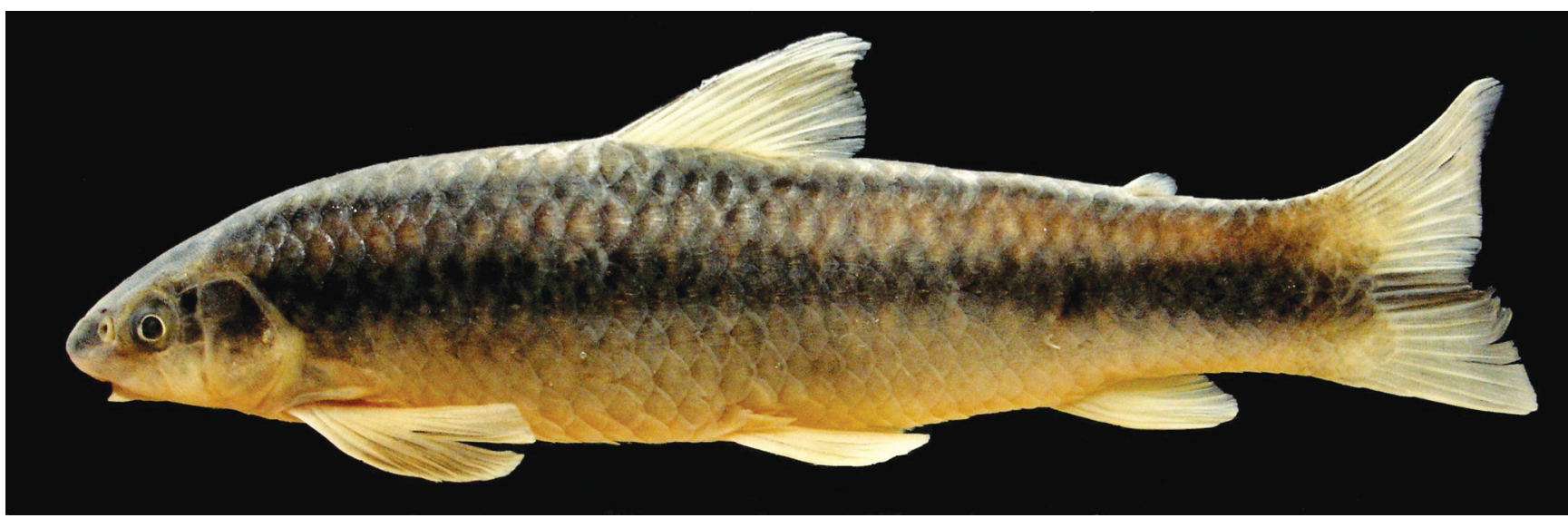

Fig. 8. Parodon magdalenensis, Holotype, ICN 17099, 108.6 mm SL, Colombia, Caldas, Norcasia, La Miel River at escape tunnel, middle Magdalena River drainage.

margin of nares; nares at level of eye, rounded, membrane present but not projecting nor separating orifices into separate halves. Mouth ventral, upper lip absent. Ventral profile of body round from isthmus to anal-fin origin then concave to caudal fin. Caudal peduncle compressed.

Premaxillary hemiseries with four teeth; maxilla with two. Lower jaw with 2-3 lateral teeth. Premaxillary teeth arranged in straight line, each with straight inferior margin laterally with curved portion that includes one or two cusps, total cusps 11-15. Teeth fit into space to receive them in lower jaw. Lower jaw with 1-3 unicuspid, outwardly curved, lateral teeth, best observed in adults, in juveniles often covered by soft tissue and poorly developed, not visible when jaws closed. Maxillary teeth 1-3, smaller than those of premaxilla, multicuspid, often covered by soft tissue.

Pectoral fin short, not reaching pelvic-fin insertions, located at vertical through opercular membrane, truncate in shape with third to fifth branched rays longer than rest. Pelvic fin not reaching anal fin; reaching, but do not surpassing, genital pore in individuals below $80 \mathrm{~mm}$ SL. In larger specimens pelvic fins fall one scale short of genital pore, first two branched rays longer than remaining. Pelvic fin at vertical through middle of dorsal-fin base. Anal fin truncate, at vertical through point three scales anterior to adipose fin, with first two branched rays longer than remaining, but not reaching caudal fin. Dorsal fin truncate, second unbranched and first branched rays longest, origin located at vertical through point half way between pectoral and pelvic insertions. Its posterior tip not reaching vertical through tips of pelvic fin, and falling short of adipose-fin origin by six scales. Adipose fin with dark base, origin at vertical through posterior portion of anal fin. Caudal fin bilobed, upper lobe longer than lower, its proximal third heavily covered with scales. In specimens over $100 \mathrm{~mm}$ SL, scales extend even further on fin.

Lateral line complete, with 35-38 pored scales, sometimes extending onto base of caudal fin. Predorsal and ventral regions with scales arranged regularly. Axillary scale present, about one or two normal scales in length.
Color in alcohol. Dorsal surface of snout and head black, white or dark yellow below middle of eye. Dorsum darker than rest of body, including lateral stripe. Base color gray (much lighter in juveniles) sometimes very dark yellow, mainly in specimens from La Miel River (Magdalena River drainage). Lateral stripe present above lateral line from snout to tips of middle caudal-fin rays; juveniles (34.8-74.3 mm SL) with 8-12 dorsal and ventral projections (about two scales in width) forming zigzag, more conspicuous anterior to vertical through dorsal-fin base; in some specimens below $80 \mathrm{~mm}$ SL lateral stripe lacks dorsal projections; downward projections reach only one scale below lateral stripe; sometimes stripe with neither dorsal nor vertical projections. Some individuals below $80 \mathrm{~mm}$ SL with 2-3 spots above lateral stripe over white or yellow base color. Some adults over $80 \mathrm{~mm}$ SL with lateral stripe totally diffuse, without showing any clearly defined borders or projections. Sides of body gray below lateral stripe to level of axillary scale, but of totally different shade from gray on head. Above lateral stripe no lighter colored area present, but some small gray blotches present that blend with dark base color of dorsum. Two darker stripes present along either side of supraoccipital process, above opercle.

Adults with distal black blotch on first five rays of pectoral fin, not obvious in juveniles. Chromatophores on first two rays of pelvic fin little developed and not forming well defined spot, hyaline in juveniles. Anal fin hyaline. Dorsal fin with very conspicuous black chromatophores on distal portion, first unbranched ray completely dark, but fin without well defined spots or bars. Adipose fin with black base. Ventral portion of body lighter than rest, without spots or chromatophores.

Sexual dimorphism. Nuptial tubercles almost imperceptible, even on ventral region of snout, very small and few in number, present in males over $85 \mathrm{~mm} \mathrm{SL}$.

Distribution. Known from the La Miel River and its tributaries in middle Magdalena drainage, the Paila River system and tributaries of the upper Cauca River, Colombia (Fig. 2). 


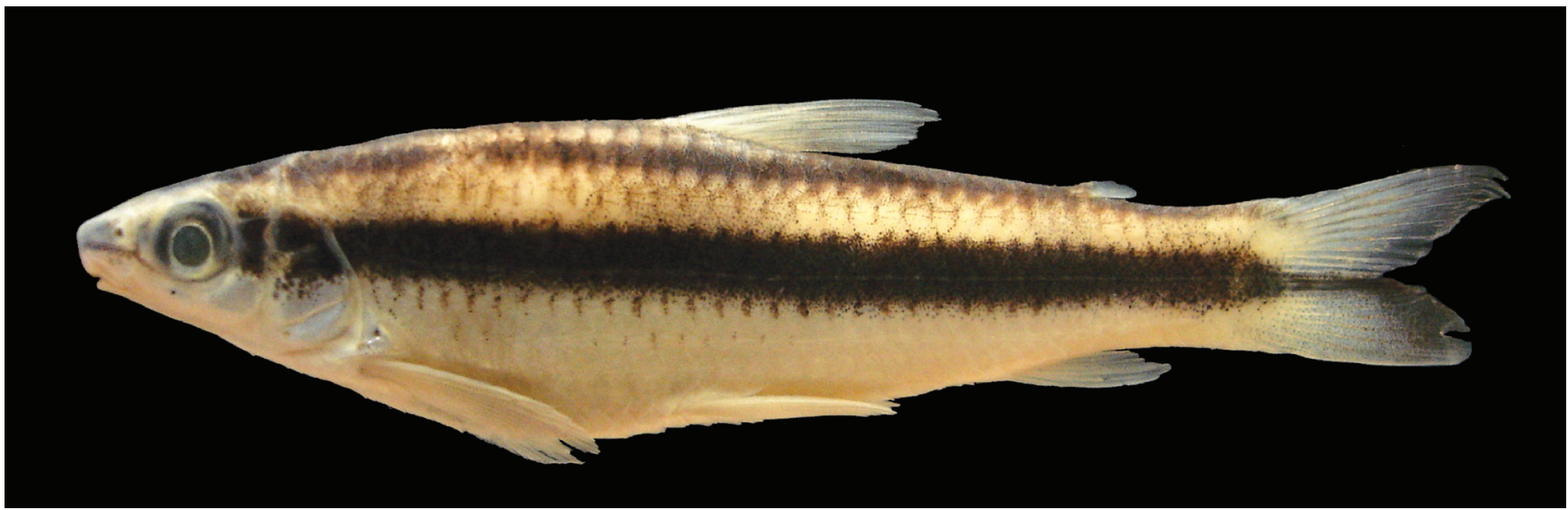

Fig. 9. Parodon pongoensis, ICN 15378, 45.9 mm SL, Colombia, Amazon River Basin, downstream from Puerto Leguizamo, Fuerte. S.B de Yaricaya, C. Yaricaya, Putumayo River drainage, Putumayo.

Etymology. The name magdalenensis refers to the Magdalena River, Colombia, in which this species is endemic.

Comments. Parodon magdalenensis is a member of the Parodon suborbitalis species group. It has the principal characteristic of the species of that group: a dark, lateral horizontal stripe with dorsal and ventral projections. Although Mago-Leccia (1970) proposed a close relationship among populations of fishes of the Lake Maracaibo basin and those of the Magdalena River basin before the rise of the Perija Mountain range, we present evidence for specific differentiation of the P. suborbitalis (Maracaibo) from those of the Magdalena. We assume that records of Eigenmann (1922), Dahl (1971) and Miles (1943) for P. suborbitalis from the Magdalena are P. magdalenensis. Specimens examined in this study from localities near those cited by them indicate that $P$. suborbitalis is not present in that system.

Eigenmann (1922) showed a figure of a $43 \mathrm{~mm}$ SL specimen (plate XIX-1) identified as P. suborbitalis from Peñas Blancas, in Antioquia, that does not show projections from the lateral stripe, but does not give counts of premaxillary tooth cusps. We examined a $48.9 \mathrm{~mm}$ SL specimen from the Miel River, Antioquia Department (IUQ 2224), that shows the same characteristics present in Eigenmann's specimen, that is, a lateral stripe without projections, and spots above that reach to dorsum. Furthermore, our specimen has a lower number of premaxillary tooth cusps in comparison to specimens from the middle Magdalena and upper Cauca sites (9vs. 11-15), as well as a higher pored lateral-line scale count (39vs. 35-38), and also to the specimens examined by Eigenmann (1922) from Peñas Blancas, which have 35-37 lateral scales. For these reasons, this specimen is identified as Parodon sp. and was not included in the analysis. Even though this specimen shares some diagnostic characters with $P$. pongoensis (a well-defined lateral stripe without dorsal or ventral projections $v s$. ill defined lateral stripe), we do not believe that it belongs to that species. It has 39 lateral scales, and the known range for $P$. pongoensis is 3438 . In addition, $P$. pongoensis has a black spot on the distal portion of the caudal rays on the lower lobe which our specimen lacks. Also, so far P. pongoensis is known only from the Amazon basin. Therefore, we conclude that the specimen IUQ 2224 is from the same population examined by Eigenmann (1922), but that it is neither $P$. suborbitalis nor $P$. pongoensis.

Cardona et al. (1998) reported on specimens of $P$. caliensis. However, we examined two specimens collected by those authors, and found them to have a color pattern totally different from that described for $P$. caliensis, which includes a lateral stripe with projections of less than one half scale length in width ( $v s$. vertical bars on sides of body, and without horizontal lateral stripe in P. caliensis), and differing meristic counts: pored lateral line scales are 36-37 in P. magdalenensis vs. 39-40 in P. caliensis. We identify the specimens we examined collected by those authors as $P$. magdalenensis.

\section{Parodon pongoensis (Allen, 1942) Fig. 9}

Apareiodon pongoense Allen, in Eigenmann \& Allen, 1942: 286 (type locality: Pongo de Manseriche, Marañón River drainage, Perú, Holotype: CAS 6757). Ortega \& Vari, 1986: 11 (distribution; records from collections). Starnes \& Schindler, 1993:757 (jaw bone illustration, comments).

Apareiodon caquetae Fowler, 1945a: 106 (type locality: Morelia, Rio Caquetá drainage, Colombia; comments; lateral view illustration; Holotype: ANSP 71696). Starnes \& Schindler, 1993: 755 (comments).

Parodon caquetae.-Böhlke, 1958: 85 (comments; tables with morphometric data). Wiley \& Collette, 1970: 166 (nuptial tubercles).

Parodon pongoense.-Géry, 1977: 203 (key; distribution; synonymy with $A$. caquetae; photograph of two live individuals).

Parodon pongoensis.-Pavanelli, 2003: 48 (synonymy; distribution; localization of type material; maximum size; common names). 
Diagnosis. Parodon pongoensis differs from all congeners in having a well-defined lateral stripe without dorsal or ventral projections ( $v s$. lateral stripe with diffuse margins and dorsal and ventral projections, or no lateral stripe), except from $P$. moreirai, from which it can be differentiated by the lower number of scales on the lateral line (34-38vs. 40-42) and the normal size of maxillary teeth ( $v s$. absence or minuteness of the teeth); by the presence of a black spot on the lower caudalfin lobe (vs. no spot on lower caudal-fin lobe); can be distinguished from P. guyanensis by the presence of four premaxillary teeth ( $v s$. five).

Description. Morphometric and meristic data given in Tables 3 and 4, respectively. Body stout. Dorsal profile of trunk straight from tip of snout to dorsal-fin origin, where angle deflects and continues straight to adipose fin, then concave to caudal fin. Ventral profile of head straight to isthmus, located at vertical through anterior part of opercle. Branchial membranes united to each other but not to isthmus. Eyes lateral; nares at level of eye, membrane of skin present but neither projected nor separating orifices into separate halves. Mouth ventral, upper lip absent. Ventral trunk profile generally rounded from isthmus to pelvic fin insertions then straight to caudal fin. Caudal peduncle compressed.

Premaxillary hemiseries with four teeth that have irregular rounded margins; with 9-12 prominent cusps thicker than in congeners; teeth fitting into space in lower jaw. Maxilla with 2-3 multicuspid teeth, smaller than those of premaxilla, and usually half covered by surrounding soft tissue. Lower jaw with 1-3 unicuspid, lateral teeth outwardly curved and not visible when mouth closed.

Pectoral fin short, not reaching pelvic-fin insertions. Truncate shaped pectoral fins inserted at vertical passing through second predorsal scale posterior to supraoccipital tip, fourth to sixth branched rays longest. Pelvic fin not reaching anal-fin origin, sometimes reaching but not surpassing genital pore. Pelvic fin at vertical through base of dorsal fin. Dorsal fin truncate, first two branched rays longest, its origin at vertical through second scale anterior to pelvic fin insertion. Anal fin at vertical through first or second scale anterior to adipose fin. Anal fin tip not reaching caudal fin. Adipose fin not reaching caudal fin; its origin at vertical through posterior margin of anal-fin base. Caudal fin bilobed, upper lobe longer, basal third covered with scales.

Lateral line with 34-38 pored scales, extended onto caudal fin. Predorsal and ventral scales regularly distributed. Axillary scale present, one or two normal scales in length.

Color in alcohol. Dorsal part of snout and head black, base color of head white or yellow below middle of eye; white spot on upper part of opercle (absent in one specimen). Dorsum of body black, just slightly lighter than lateral stripe, with diffuse white or yellow spots not forming rows or transverse bands. Two black dorsal stripes one half to one scale in width, delimiting dark dorsum, originate lateral to supraoccipital process tip and unite just posterior to adipose fin.
Body base color white to yellow, with well defined black lateral stripe that lacks dorsal or ventral projections and that initiates on snout at level of eye and continues to tips of middle caudal-fin rays. Above this black stripe three diffuse black spots; first at vertical through pectoral fin insertions, second at vertical through pelvic-fin insertions, and third at vertical through anal-fin origin.

Pectoral fin with few almost imperceptible diffuse black chromatophores. Pelvic and anal fins hyaline. Dorsal fin with chromatophores concentrated on second unbranched ray. Caudal fin with middle rays black to tips, sparse black chromatophores present on both lobes, but concentrated on lower lobe to form well defined spot. Ventral part of body same color as rest, without spots, stripes or bars.

Sexual dimorphism. Not observed, perhaps because of time of collection, or juvenile estate of specimens examined. Wiley $\&$ Collette (1970) reported nuptial tubercles in adult males.

Distribution. Middle Amazonas on Putumayo River drainage in Colombia; upper Amazonas in Peru (Fig. 2).

Comments. According to the original description, Parodon pongoensis has 49 scales in the lateral line, very different from our count. However, in the holotype we count 39 scales, suggesting that the count published by Allen (in Eigenmann \& Allen, 1942) may have been just a typographical error. His counts of scales above and below the lateral line coincide with ours (4-5).

Fowler (1945a) described Apareiodon caquetae from the Caquetá River in Colombia, but those specimens coincide in many aspects with $P$. pongoensis. We examined specimens from near the type locality of $A$. caquetae to shed light on the validity of that name. Fowler stated that $A$. caquetae had "On caudal also diffuse dark bar at bases of lower rays", a color pattern like that of $P$. pongoensis, referring to the round, dark spot on the lower caudal lobe, present on both P. pongoensis and $A$. caquetae. Fowler gave the number of lateral line scales as 33+3 and his illustration (fig. 6. p. 104) would seem to show a typical P. pongoensis. Fowler (1945a) stated "the round pale spot, about the size of the pupil, imposed on the black lateral band at the upper part of the opercle." We observed that there is a white spot on upper part of the opercle, that even though it was observed in the majority of specimens here examined, is not so evident as might be indicated by Fowler's illustration, but could be effect of fixation. We maintain the synonymy of $A$. caquetae with $P$. pongoensis, in agreement with Pavanelli (2003), Böhlke (1958) and Starnes \& Schindler (1993), on the basis of color pattern and meristics.

Starnes \& Schindler (1993) illustrated the jaw bones and part of the suspensorium of a specimen identified as " $A$. pongoense" (USNM 216400), but did not show teeth present on the lower jaw. In any case, according to our findings, in specimens smaller than $50 \mathrm{~mm}$ SL the dentary teeth are often covered by soft tissue or reduced and not easily visible. Thus, due the small size of this specimen, $43 \mathrm{~mm} \mathrm{SL}$, this feature 
may have been overlooked by the authors and not illustrated. So the illustration should not be taken as indicative of the condition for this species.

Böhlke (1958) discussed Fowler's (1945a) Apareiodon caquetae (= Parodon pongoensis), and identified it as $P$. caquetae based on the characters that traditionally have been used to separate the genus Apareiodon and Parodon: "Apareiodon is in all respects like Parodon except that there are no teeth in the side of the lower jaw. The ampulla on the upturned edge of the lower jaw, with which the teeth are associated in Parodon, is less well developed in this genus (Eigenmann, 1916)". When Böhlke (1958) examined Fowler's specimens, he found teeth present on the dentary just as we have found them in specimens from sites in the Caquetá River drainage, near the type locality of $A$. caquetae. In any case, this species is also a synonym of $P$. pongoensis since $P$. caquetae and $A$. caquetae are the same species.

Material examined. Peru. CAS 6757, holotype of Apareiodon pongoense, $62.0 \mathrm{~mm}$ SL, Puerto Melendez, upper Amazon, Pongo de Manseriche, small woodland stream opposite. AMNH 217981, 1, $66.8 \mathrm{~mm} \mathrm{SL}$, Iquitos, Loreto, Iquitos, upper río Amazonas. Colombia. SU 50671, 15, 41.1-48.0 mm SL, Caquetá, río Amazon basin, small stream across the río Orteguaza from Tres Esquinas (same streams as sta. 1). SU 53673, 4, 51.3-71.0 mm SL, Caquetá, río Amazon basin, upper río Orteguaza, Puerto Lara near Florencia. IUQ 2085, 1, $43.9 \mathrm{~mm}$ SL, Putumayo, Puerto Leguizamo, río Putumayo, $00^{\circ} 11^{\prime} \mathrm{S}, 7^{\circ} 47^{\prime} \mathrm{W}$. ICN 15380, 1, $56.8 \mathrm{~mm}$ SL, Putumayo, Pto. Leguizamo, río Putumayo. ICN 15378, 1, $45.9 \mathrm{~mm}$ SL, Putumayo, Pto. Leguizamo, downstream Puerto Leguizamo in front of S.B Yaricaya, C. Yaricaya, río Putumayo drainage. Ecuador. BMNH 1981. 1. 5. 603-606, 4, 43.0-50.3 mm SL, río Amazon basin, upper Amazon.

\section{Parodon suborbitalis Valenciennes, 1850 Figs. 10-11}

Parodon suborbitale Valenciennes, in Cuvier \& Valenciennes, 1850: 51 (type locality: Lake Maracaibo basin, Venezuela, $9^{\circ} 55^{\prime} \mathrm{N} 71^{\circ} 35^{\prime} \mathrm{W}$; Lectotype: MNHN 0000-1807, $97.0 \mathrm{~mm}$ SL, by present designation). Schultz, 1944: 289 (diagnosis in key; description; lateral view illustration; morphometric data tables, distribution). Géry, 1959: 485 (illustration of premaxillary teeth). Wiley \& Collette, 1970: 166 (presence of nuptial tubercles). Géry, 1977: 203; 208 (key; distribution; photo of live fish that is actually $P$. apolinari).

Parodon suborbitalis.-Steindachner, 1879: 21 (synonym with P. nasus). Berg, 1897: 280 (recognition of $P$. suborbitalis as valid species, not synonym of $P$. nasus). Eigenmann \& Allen, 1942: 285 (brief description). Fowler, 1945a: 107 (brief description). Pavanelli, 2003: 48 (synonymy, distribution, location of type material, maximum size, common names).

Diagnosis. Parodon suborbitalis differs from all congeners in having the dorsal portion of body light colored with a series of transverse brown bars that do not unite with dorsal projections of lateral stripe ( $v s$. dorsal part of body dark, without bars that unite with dorsal projections of lateral stripe); caudal-fin base covered with scales for less than one third length ( $v s$. one third or more of caudal fin covered with scales); middle caudal-fin rays pigmented for only one half or less of their length ( $v s$. middle caudal-fin rays dark to tips). It is further distinguished by the number branched pectoral rays (14-17) from P. alfonsoi (12-14), P. atratoensis (12-13), P. caliensis (12-13), P. magdalenensis (11-14) and P. pongoensis (11-14); and can be differentiated from $P$. bifasciatus by the higher number of cusps in premaxillary teeth (15-17 vs. 7-12). It differs from P. nasus by the presence of spots on the sides of body above the lateral stripe (vs. no spots on the body above the lateral stripe); from $P$. guyanensis by the number of teeth on the premaxilla (4 vs. 5); and from P. pongoensis and P. moreirai by the presence of a lateral stripe with projections above and below ( $v s$. absence of projections in such a stripe); the number of scales in the lateral line (35-38 vs. 40-42 in P. moreirai), and normal sized teeth in the maxilla ( $v s$. teeth minute or absent). It can be distinguished from $P$. carrikeri by the dark coloration along the body including most of the head (vs. ground and general color of body light in $P$. suborbitalis).

Description. Morphometric and meristic data given in Tables 1 and 2, respectively. Body stout. Dorsal profile of head straight from tip of snout to tip of supraoccipital. Dorsal trunk profile convex from tip of supraoccipital to dorsal-fin origin, then straight to caudal fin. Ventral profile of head straight to pectoralfin insertions. Branchial membranes united to each other but free from isthmus, isthmus at vertical at two scales posterior to end of supraoccipital. Eyes lateral; nares at level of eye, with membrane of skin, but not projecting nor dividing them into separate orifices. Mouth ventral, upper lip absent. Ventral profile of trunk rounded from pectoral-fin insertions to anal-fin origin, then straight to caudal fin. Caudal peduncle compressed.

Premaxillary hemiseries with four multicuspid teeth arranged in straight line, each with inferior margin straight and divided into 15-17 small cusps; teeth fitting into space in lower jaw. Maxilla with one or two multicuspid teeth, smaller than those of premaxilla, and half covered by surrounding soft tissue. Lower jaw with two or three unicuspid, outwardly curved lateral teeth, not observed when mouth closed.

Pectoral fin short (Table 1), not reaching pelvic-fin insertions; located at vertical through tip of supraoccipital, truncate and with sixth branched ray longest. Pelvic fin not reaching genital pore (sometimes surpassing it by one scale in individuals over $50 \mathrm{~mm}$ SL but not reaching anal-fin origin). Pelvic fin at vertical through middle of dorsal-fin base. Dorsal fin truncate, first three rays (two simple and first branched) longest. Dorsal fin at vertical through midpoint between pectoral and pelvic-fin insertions, or closer to latter. Anal fin at vertical through two or three scales anterior to adipose-fin origin. Adipose fin not reaching caudal fin, located at vertical through posterior margin of anal-fin base. Caudal fin with two lobes of equal length (in individuals smaller than $50 \mathrm{~mm} \mathrm{SL}$ ); in adults, upper caudal-fin lobe longer than lower. Base of caudal fin covered with scales for less than one third of its length. 


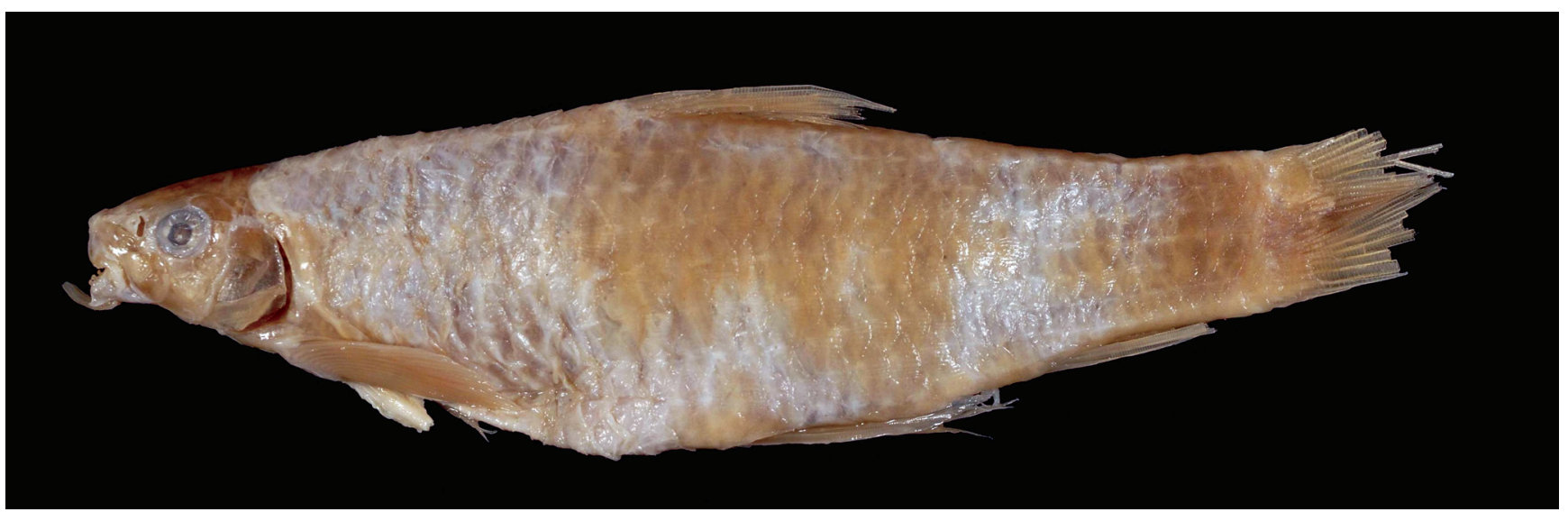

Fig. 10. Parodon suborbitalis, Lectotype, MNHN 1807, $97 \mathrm{~mm}$ SL, Venezuela, Lake Maracaibo basin (Photo by Romain Causse, MNHN).

Lateral line complete with 37-39 pored scales, but usually not extending onto scaled portion of caudal fin. Predorsal and ventral scales regularly distributed. Axillary scale present, one to two normal scales in length.

Color in alcohol. Dorsal surface of snout and head dark brown with light yellow spots; yellow below level of middle of eye. Dorsum of body of same color as lateral stripe, dark brown, and crossed by 7-8 transverse bars that begin two scales posterior to tip of supraoccipital and extend to base of caudal fin; bars delimited on both sides of body by two lighter brown narrow stripes (less than one scale in width), that extend posteriorly from supraoccipital to caudal fin without uniting with stripe from opposite side.

Base color of body light brown; lateral stripe with 11-16 elongate (sometimes rounded) spots extending both dorsal and ventrally to give zigzag appearance. This pattern more conspicuous in juveniles. Spots not united with transverse bars of dorsum. Three or four long wide spots between lateral and dorsal stripes, longer and wider than those above lateral stripe. Lateral stripe extending for only half length of middle caudal-fin rays.

Pectoral fin with small light brown spot on distal portion of first four rays in adults; pelvic, anal, and adipose fins hyaline. Dorsal fin with small chromatophores scattered over most of fin but not forming bars or spots. Caudal fin with middle rays brown, remaining rays with dispersed chromatophores, not forming spots or bars, more visible in juveniles. Venter lighter than rest of body, no spots nor chromatophores present.

Sexual dimorphism. No males examined had nuptial tubercles, but these structures were reported for this species by Wiley $\&$ Collette (1970).

Distribution. Lake Maracaibo basin (Fig. 2).

Comments. Valenciennes (in Cuvier \& Valenciennes, 1850) gave no catalog numbers and did not indicate the location of the type specimens he used to describe $P$. suborbitalis. Most of his description was centered on the position of the mouth, the premaxillary teeth and its absence for half the length of the lower jaw. He did not describe pigmentation pattern or whether the lateral stripe had projections of any kind. The specimens he used were located in the MNHN of Paris, France (see material examined), and we obtained photos and radiographs of them. However, pigmentation pattern could not be determined because of the age-faded condition of those 200 year-old specimens (collected in 1807). The specimens deposited at the MNHN are syntypes according to Romain Causse (pers. comm.). For this reason, the material examined from the Lake Maracaibo basin is maintained as P. suborbitalis principally on the basis of the collection site. No other species from the Lake Maracaibo basin have ever been reported in sympatry with P. suborbitalis.

In light of this, we designate as lectotype of $P$. suborbitalis, in accordance with Article 74, and the corresponding recommendations and paragraphs of the International Code of Zoological Nomenclature (1999), the specimen MNHN 0000$1807,97.0 \mathrm{~mm}$ SL (see material examined).

Parodon suborbitalis was presumed to be widely distributed in northern South America and was reported by Eigenmann (1922); Miles (1943; 1947); Dahl (1971); Mojica et al. (2002); Maldonado et al. (2005); Ortega-Lara et al. (2006); and Villa-Navarro et al. (2006) from the Magdalena and Cauca River drainages. However, this is not the case and as we have shown here (see comments on P. magdalenensis), in spite of the relationship between the Magdalena River and the Lake Maracaibo fish faunas (Mago-Leccia, 1970; Kellogg, 1984), several distinct species with more restricted distributions exist in this region. Parodon suborbitalis is endemic to the Maracaibo Lake basin (Colombia and Venezuela).

Material examined. Venezuela. MNHN 0000-1807, lectotype, 97.0 mm SL and MNHN B-2995, 2 paralectotypes, 96.0-100.1 mm SL, Lake Maracaibo Basin, 9`55'N, 71³5'W. UF 21795, 1, 104.6 mm SL, Zulia, Lake Maracaibo basin, stream about $10 \mathrm{~km}$ N of Mene Grande. UF 30756, 2, 70.2-92.1 mm SL, Táchira, La Fría and La Honda, Lake Maracaibo basin, río Orope at bridge between La Fría \& La Honda at km marker 817. UF 25445, 1, 74.3 mm SL, Lake Maracaibo basin, 


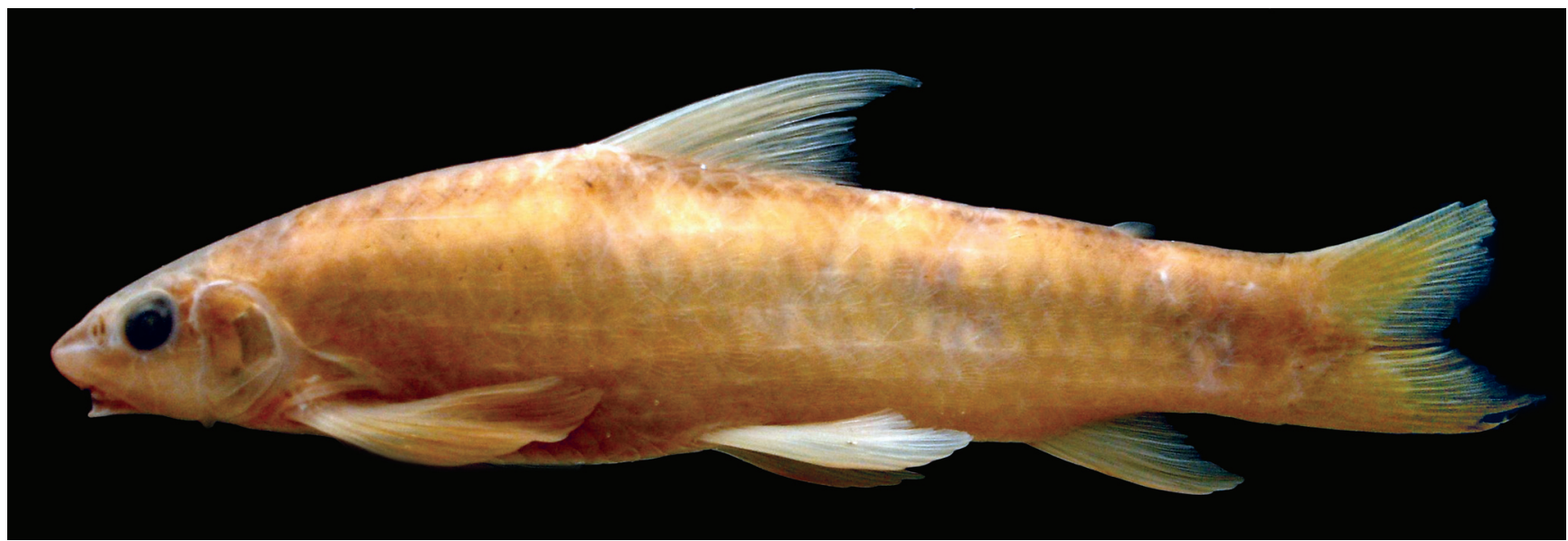

Fig. 11. Parodon suborbitalis, UF 21795, $104.6 \mathrm{~mm}$ SL, Venezuela, Lake Maracaibo basin, creek about $10 \mathrm{~km}$ N of Mene Grande, Zulia.

Zulia, Libertad, creek above La Misión de Los Ángeles. INHS 34885 , 1, $48.3 \mathrm{~mm}$ SL, Lake Maracaibo basin, Zulia, Machiques, río Negro and tributaries, $16 \mathrm{~km} \mathrm{~W} 10^{\circ} 02^{\prime} \mathrm{N}, 72^{\circ} 40^{\prime} \mathrm{W}$. INHS $60367,5+1 \mathrm{c} \& \mathrm{~s}$, 44.0-57.8 mm SL, Lake Maracaibo basin, Trujillo, La Victoria, Mimbos Creek (río Caus drainage) $2 \mathrm{~km}$ from La Victoria, $9^{\circ} 19^{\prime} \mathrm{N}, 70^{\circ} 50^{\prime} \mathrm{W}$. INHS 60567, 1, 46.0 mm SL, Zulia, Tucoco, Lake Maracaibo basin, río Yasa (río Palmar drainage) $5 \mathrm{~km} \mathrm{~S}$ of Machiques on road to Tucoco. INHS 28813, 2, 41.3-44.1 mm SL, Trujillo, San Antonio, Lake Maracaibo basin, río Monay (río Motatan drainage) at bridge on highway to San Antonio 9³9’N, 70²5’W. UMMZ 145393,1 of 2, 108.4 mm SL, San Rafael de Poco, Maracaibo drainage, 1931. Colombia. IAvH 9754, 6, 57.4-107.7 mm SL, Norte de Santander, Lake Maracaibo basin, río Catatumbo drainage, Mijagual creek, $7^{\circ} 40^{\prime} \mathrm{N}, 7^{\circ} 24^{\prime} \mathrm{W}, 423$ masl. IAvH 9755, 1, $86.1 \mathrm{~mm}$ SL, Norte de Santander, Lake Maracaibo basin, río Catatumbo drainage, La Maravilla Creek, 441 masl. IAvH 9756, 1, 85.3 mm SL, Norte de Santander, Lake Maracaibo basin, río Catatumbo drainage, Burbura Creek, 570 masl. IAvH 9757, 1, 54.1 mm SL, Norte de Santander, Lake Maracaibo basin, río Catatumbo drainage, before El Diviso, 410 masl. IAvH 9769, 29, 77.9-131.0 mm SL, Norte de Santander, Lake Maracaibo basin, río Catatumbo drainage, Caño Seco, $8^{\circ} 34^{\prime} \mathrm{N}, 73^{\circ} 10^{\prime} \mathrm{W}, 355$ masl.

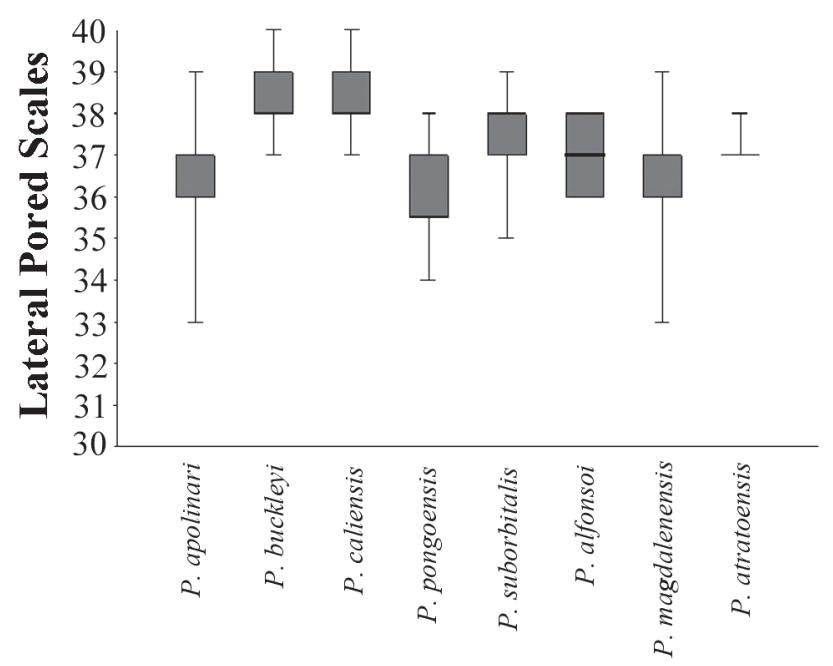

Fig. 12. Number of pored scales of lateral line of Colombian species of Parodon.

\section{Discussion}

Posada (1909) described Parodon medellinense, called "mazorca" in the region around Medellin, Colombia, where it was found. His description caused confusion, however, because he stated that: "the fins also have transverse spots, being better marked on the tail", which is a characteristic of the very similar Saccodon dariensis. The original description goes on to mention that: "the lower jaw only has teeth on the sides", a characteristic of the genus Parodon, but not Saccodon. The total number of rays in the pectoral fin (20) and caudal fin (23) are also given, but these numbers are higher than any subsequent counts for species of either genus, which usually have 17 or fewer pectoral-fin rays, and caudal-fin ray counts that don't surpass 20 . Since no illustration of the specimens used by Posada was given, it has been impossible to unequivocally assign $P$. medellinense to either Parodon or Saccodon.

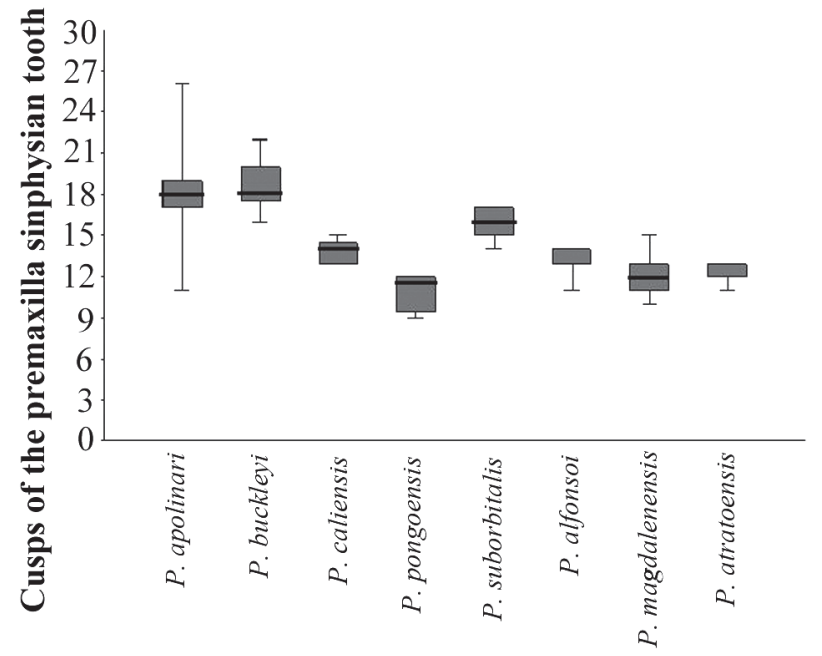

Fig. 13. Number of cusps present on premaxillary tooth at symphysis of Colombian species of Parodon. 


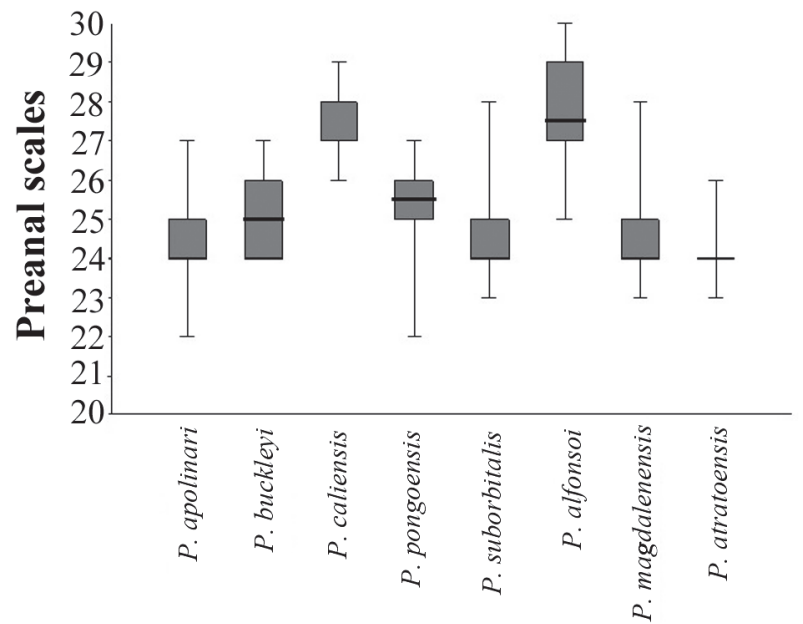

Fig. 14. Number of preanal scales of Colombian species of Parodon.

We here support recognition of the "Parodon suborbitalis species group", on the basis of the similarity of pigmentation pattern, in particular the lateral stripe, and the geographic distribution of the species. This is in agreement with the definition of the group proposed by Pavanelli (1999). This group now includes the following species: $P$. alfonsoi, $P$. atratoensis, $P$. bifasciatus, $P$. buckleyi, $P$. carrikeri, $P$. hilarii, $P$. magdalenensis, $P$. nasus, and $P$. suborbitalis.

Four specimens were analyzed from the Porce River, Cauca River basin, Colombia (IUQ 2386; AMNH 249085; IUQ 2220; IUQ 2384). Those specimens showed different coloration patterns and some meristic and osteological characters of Parodon suborbitalis (type species of the genus), $P$. magdalenensis, and $P$. caliensis (species present at the Cauca River basin). Nevertheless and in spite that we consider those characters adequate to distinguish this population from the species mentioned above, we believe that it is better to maintain the examined material as Parodon sp., until a greater number of specimens becomes available for study.

Additional material is difficult to obtain because fish populations of the lower Cauca River are heavily impacted by human activities especially the removal of sand and gravel for construction, and pollution by domestic and industrial effluents. This is also the case for Parodon caliensis, which has suffered similar decimation of its populations and has disappeared from sites where we once easily collected it (Londoño-Burbano \& Román-Valencia, 2010).

Specimens from the Ranchería River an independent drainage that empties into the ocean that forms part of the Caribbean coastal drainages of the Colombian Guajira, were examined. Apparently this population is not in contact with populations of Parodon present in the nearby Maracaibo basin to the East. Those fishes were found to be different from P. suborbitalis and P. carrikeri. They differ from the latter in having a lighter body base color, a deeper and stouter body shape, fewer cusps on the premaxillary teeth (12-18 vs. 20), and fewer pored lateral-line scales (35-37 vs. 39). Two specimens (FMNH 56306 and CAS 6782) from Soplaviento,
Bolívar Department, lower Magdalena River, could not be distinguished from that population, except by a very unusual dorsal-fin ray count (iii,9) and the number of circumpeduncular scales, which was 16 (vs. 15 on Ranchería River specimens), as in all other species of Parodon. So, we identify that material as Parodon sp. until more specimens can be obtained.

Apareiodon orinocensis, a species present in the Venezuelan Orinoco, has not yet been recorded from the Colombian Orinoco, in agreement with the findings of Pavanelli (2003) and this study.

\section{Key to Colombian species of Parodon}

1. Sides of body with independent vertical bars, lateral stripe absent

1'. Sides of body without independent vertical bars, lateral stripe present ....................................................................... 3

2. Sides of body with 14-17 vertical bands, each band about one scale in width; premaxillary teeth with 14-26 small cusps; adults often with first dorsal-fin rays elongated, sometimes reaching adipose fin when depresse P. apolinari (Orinoco basin)

2 '. Sides of body with 6-8 vertical bands, each band two to three scales in width; premaxillary teeth with 13-15 small cusps; first dorsal-fin rays not elongated, never reaching adipose fin when depressed ................................ P. caliensis (Upper río Cauca drainage)

3. Lateral stripe brown, with projections that have indistinct margins; lower caudal-fin lobe without bars or dark spots

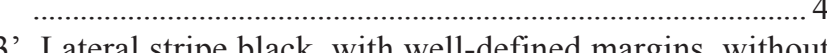
projections; lower caudal-fin lobe with black spot ........................ P. pongoensis (Middle río Amazonas basin)

4. Lateral stripe with both dorsal and ventral projections; all fins hyaline or with few chromatophores that never form distinct spots or bars; base color of body dark or light yellow, white or light brown

.... 5

4'. Ventral projections of lateral stripe extending down to level of axillary scale; area above lateral stripe dusk, almost black; pectoral fin with black distal spot; base color of body gray, darker than many congeners ...................... P. magdalenensis (Middle río Magdalena and upper río Cauca drainages)

5. Dorsal stripe present on either side of body; spots present on body above lateral stripe; 22-27 preanal scales; no

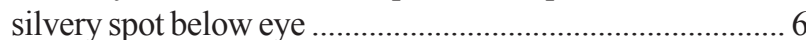

5'. Dorsal stripes absent; no spots above lateral stripe; 27-30 preanal scales; conspicuous silvery spot below eye

P. alfonsoi (Lower río Magdalena drainage)

6. Lateral stripe extending to tips of middle caudal-fin rays; proximal third of caudal fin covered with scales; pectoral fin with 11-14 branched rays ................................................ 7

6'. Lateral stripe not continuing to tips of middle caudal-fin rays; less than one third of caudal fin covered with scales; pectoral fin with 14-17 branched rays ......... P. suborbitalis (Lake Maracaibo Basin)

7. Projections of lateral stripe not reaching dorsal part of body; transverse dorsal spots present from one or two scales 
posterior to tip of supraoccipital process to adipose-fin origin; premaxillary teeth with 12-13 small cusps; lateral line with $37-38$ pored scales ............................. P. atratoensis (río Atrato drainage)

7'. Projections of lateral stripe anterior to dorsal fin extending over dorsum of body to connect with those of other side, forming continuous bands; dorsal spots present from tip of supraoccipital process to caudal fin; premaxillary teeth with 16-18 small cusps; lateral line with 39-40 pored scales P. buckleyi

(Middle río Amazonas Basin)

Comparative material examined. Parodon bifasciatus: BMNH 1972. 7. 27. 897-899, 2, 47.0-48.3 mm SL, Guyana, Rupununi. BMNH 1972. 7. 27. 900-901, 2, 62.0-88.5 mm SL, Guyana, Rupununi. Parodon guyanensis: IUQ 2312, ex ANSP 189168, 5, 69.3-83.8 mm SL, Guyana, Rupununi, río Essequibo at Kassi-Attae rapids, $5.5 \mathrm{~km}$ SE of mouth of río Kuyuwini $02^{\circ} 13^{\prime} 36^{\prime \prime N} 058^{\circ} 17^{\prime} 38^{\prime \prime W}$. Parodon carrikeri: AMNH 233323, 1, 70.5 mm SL, Bolivia, Ichilo Province, Amboro National Park, Mataracu camp, río Verde, 17³3'12”S 6352'18'W. Parodon nasus: UMMZ 206412, 4 of 7, 83.7-122.4 $\mathrm{mm}$ SL, Paraguay, Canendiyu, small pool along cascading stream into río Parana at Salto del Guaira on border between Paraguay and Brazil. UMMZ 208048, 6 of 11, 105.2-110.8 mm SL, Paraguay, Caaguazu, río Tabicuary-mi ca $20 \mathrm{~km} \mathrm{~S}$ of Coronel Oviedo on paved hwy (at bridge) to Villarica, río Paraguay drainage. Parodon hilarii: UMMZ 66493, 4 of 8, 77.6-94.8 mm SL, Bolivia, río Colorado, 10 mi above Huachi; trib. to río Bopi, río Beni-Amazonas drainage. Parodon sp.: IUQ 2224, 1, 48.9 mm SL, Colombia, Middle río Magdalena drainage, río La Miel. IUQ 2386, 1, 87.3 mm SL, Colombia, Antioquia, lower río Cauca system, Riachón Creek, río Porce drainage, 659'11.1”N 7504'31.5”'W, 635 masl. AMNH 249085, 2, 79.2-81.4 mm SL, Colombia, Antioquia, lower río Cauca system, Riachón Creek, río

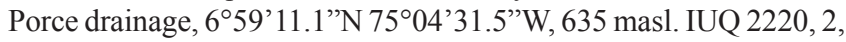
60.2-74.0 mm SL, Colombia, Antioquia, lower río Cauca system, Riachón Creek, río Porce drainage, 659'11.1'N 7504'31.5”'W, 635 masl. IUQ 2384, 1 c\&s, 64.2 mm SL, Colombia, Antioquia, lower río Cauca system, Riachón Creek, río Porce drainage, 659'11.1" N, 7504'31.5”', 635 masl. ICN 11602, 1, 110.1 mm SL, Colombia, Guajira, Marocaso, Caribbean-Guajira slopes, río Ranchería drainage, río Marocaso. 1152'09.52”N , 72॰13'29.68”W, 20 masl. ICN 9650, 2, 100.1-103.2 mm SL, Colombia, Cerrejón Mine, Bocatoma sur, río Ranchería. ICN 10836, 1, 82.9 mm SL, Colombia, río Ranchería. ICN 9696, 3, 95.7-96.7 mm SL, Colombia, Corregimiento Chorreras, Paso Ancho, río Ranchería. ICN 10798, 4, 47.5-57.8 mm SL, Colombia, Riohacha, near village of Aremasahin, río Ranchería. FMNH 56306, 1, 110.5 mm SL, Colombia, Bolivar, Soplaviento, Caribbean-Guajira slopes. CAS 6782, 1, 97.2 mm SL, Colombia, Bolivar, Soplaviento, Caribbean-Guajira slopes, town on the dike de Cartagena between Cartagena and Calamar. ICN 813, 3, 94.0-126.4 mm SL, Colombia, Guajira, Caribbean-Guajira slopes, Tabaco stream. Saccodon dariensis (all from Colombia): IUQ 1673, 3, 58.4-65.8 mm SL, Quindío, Quimbaya, río Roble, tributary of río Vieja in Ocaso Reserve, $100 \mathrm{~m}$ below Playa Azul foot bridge, 4³5'68'N 7552'81'”W. IUQ 1672, 2 , 37.1-38.1 mm SL, Valle del Cauca, Zarzal, Las Cañas Creek, tributary of río Cauca, on road to Zarzal, 4²1'09'N 7604'11'W. IUQ 1954, 2, 32.4-39.0 mm SL, Valle del Cauca, Zarzal, río Cauca drainage, Las Cañas Creek, tributary of río Cauca on Zarzal-La Paila road. IUQ 2222, ex CP-UCO 336, 2, 105.6-134.4 mm SL, Antioquia, San Rafael, Arenal Creek. IUQ 2219, ex CP-UCO 4, 2, 96.7-131.0 mm SL, Antioquia, Samaná, río Magdalena drainage, río La Miel at its mouth with río Tasajos at La Miel. IUQ 1219, 1, $108.9 \mathrm{~mm}$ SL, Quindío, upper río Cauca drainage, río La Vieja. IUQ 896, 1, $56.1 \mathrm{~mm} \mathrm{SL}$, Quindío, río La Vieja at Puerto Alejandría. IUQ 777, 1, 143.8 mm SL, Quindío, La Tebaida, río La Vieja at Alambrado.

\section{Acknowledgements}

We thank the following for the loan of specimens or photographs and $\mathrm{x}$-rays of specimens in their care: Barbara Brown and Scott Schaefer (AMNH), Mark H. Sabaj-Pérez (ANSP), James Maclaine (BMNH), David Catania and Mysi Hoang (CAS), Juan G. Ospina and Henry Agudelo (CIUA), Gabriel Roldán and María I. Ríos (CP-UCO), Mary A. Rogers, Kevin Swagel, and Phil Willink (FMNH), Juan D. Bogotá (IAvH), Jaime Aguirre and Angela Gutierrez (ICN), Mike Retzer (INHS), Andrew Williston and Karsten Hartel (MCZ), Paulo A. Buckup (MNRJ), Romain Causse (MNHN), Rob Robins and Larry Page (UF), Douglas Nelson and William Fink (UMMZ), and Peter D. Rask (ZMUC). For sending literature and advice about parodontid and characiform taxonomy we thank Carla S. Pavanelli (NUP), William Eschmeyer (CAS), Richard P. Vari (USNM), Carl Ferraris Jr. (CAS), Wayne Starnes (NCSM), and Martine Desoutter (MNHN). We thank Roberto E. Reis (MCP), Mário de Pinna (MZUSP), Raquel I. Ruiz-C (IUQ), and three anonymous referees for their comments and corrections which help to improve this manuscript. Paulo A. Buckup revised the abstract in Portuguese.

\section{Literature Cited}

Berg, C. 1897. Contribuciónes al conocimiento de los peces Sudamericanos, especialmente de los de la República Argentina. Anales del Museo Nacional de Buenos Aires, 5: 263-302.

Böhlke, J. E. 1958. Studies on the fishes of the family Characidae. A report on several extensive recent collections from Ecuador. Proceedings of the Academy of Natural Sciences of Philadelphia, 110: 1-121.

Boulenger, G. A. 1887. An account of the fishes collected by Mr. C. Buckley in eastern Ecuador. Proceedings of the Zoological Society of London, 2: 274-283.

Boulenger, G. A. 1895. LXVI. Description of a new Characinoid fish of the Genus Parodon. Annals and Magazine of Natural History, including Zoology, Botany, and Geology, 16: 480.

Britski, H. A. 1972. Peixes de água doce do Estado de São Paulo. Sistemática. Pp. 79-108. In: Comissão Interestadual da Bacia Paraná-Uruguai. Poluição e Piscicultura. São Paulo: Faculdade de Saúde Pública da USP/Instituto de Pesca.

Cardona, M., C. Román-Valencia, J. L. Jiménez \& H. Hurtado. 1998. Composición y diversidad de los peces de la quebrada San Pablo en Alto Cauca, Colombia. Boletín Ecotrópica: Ecosistemas Tropicales, 32: 11-24.

Cuvier, G. \& A. Valenciennes. 1850. Histoire naturelle des poissons. Tome vingt-deuxième. Suite du livre vingt-deuxième. Suite de la famille des Salmonoïdes: 634- 650.

Dahl, G. 1971. Los peces del norte de Colombia. Bogotá: Instituto de Desarrollo de los Recursos Naturales Renovables/INDERENA/ Ministerio de Agricultura. Bogotá, 391p.

Eigenmann, C. H. 1916. On Apareiodon, a new genus of characid fishes. Annals of the Carnegie Museum, 10: 71-76.

Eigenmann, C. H. 1922. The fishes of Western South America, Part I. 
The fresh-water fishes of Northwestern South America, including Colombia, Panama, and the pacific slopes of Ecuador and Peru, together with an appendix upon the fishes of the Rio Meta in Colombia. Memoirs of the Carnegie Museum, 9: 1-277.

Eigenmann, C. H. \& W. R. Allen. 1942. Fishes of Western South America: I. The Intercordilleran and Amazonian Lowlands of Peru. II. The High Pampas of Peru, Bolivia, and Northern Chile. With a revision of the Peruvian Gymnotidae, and of the genus Orestias. Lexington, The University of Kentucky, 494p.

Eschmeyer, W. N. (ed.) Catalog of Fishes electronic version (19 February 2010). http://research.calacademy.org/ichthyology/ catalog/fishcatmain.asp.

Eschmeyer, W. N. \& J. D. Fong 2010. Species of Fishes by family/ subfamily. On-line version dated 14/07/2011. http:// research.calacademy.org/research/ichthyology/catalog/ SpeciesByFamily.asp

Ferraris, C. J., Jr. 2007. Checklist of catfishes, recent and fossil (Osteichthyes: Siluriformes), and catalogue of siluriform primary types. Zootaxa, 1418: 1-628.

Fowler, H. W. 1943. A collection of fresh-water fishes from Colombia, obtained chiefly by Brother Nicéforo Maria. Proceedings of the Academy of Natural Sciences of Philadelphia, 95: 223-266.

Fowler, H. W. 1945a. Colombian zoological survey. Part I. - The fresh-water fishes obtained in 1945. Proceedings of the Academy of Natural Sciences of Philadelphia, 97: 93-135.

Fowler, H. W. 1945b. Descriptions of two new fresh-water fishes from Colombia. Notulae Naturae, 158: 1-11.

Géry, J. 1959. Contributions a l'étude des poissons Characoides Parodon guyanensis n. sp. de Guyane Française, avec quelques considérations sur le groupe (Hemiodontinae). Bulletin du Muséum National d'Histoire Naturelle, 2: 481-490.

Géry, J. 1977. Characoids of the world. Neptune City, T.F.H, 672p.

International Code of Zoological Nomenclature. 1999. International Commission of Zoological Nomenclature. 4 ed. The Natural History Museum, London, 306p.

Jesus, C. M., L. A. C. Bertollo \& O. Moreira-Filho. 1999. Comparative cytogenetics in Apareiodon affinis (Pisces, Characiformes) and considerations regarding diversification of the group. Genética, 105: 63-67.

Kellogg, J. N. 1984. Cenozoic tectonic history of the Sierra de Perijá, Venezuela-Colombia, and adjacent basins. Geologic Society of America, 162: 239-261.

Londoño-Burbano, A. \& C. Román-Valencia. 2010. Redescripción de Parodon caliensis y Saccodon dariensis (Characiformes: Parodontidae). Revista de Biología Tropical, 58: 813-826.

Mago-Leccia, F. 1970. Lista de los peces de Venezuela, incluyendo un estudio preliminar sobre la ictiogeografía del país. Caracas: Ministerio de Agricultura y Cría/Oficina Nacional de Pesca, 283p.

Maldonado, J. A., A. Ortega-Lara, S. Usma, V. G. Galvis, F. A. VillaNavarro, S. Prada \& C. Ardila. 2005. Peces de los Andes de Colombia. Instituto de Investigación de Recursos Biológicos "Alexander von Humboldt", Bogotá, 346p.

Maldonado, J. A., F. A. Villa, A. Ortega, S. Prada, U. Jaramillo, A. Claro, J. S. Usma, T. S. Rivas, W. Chaverra, J. F. Cuesta \& J. E. García. 2006. Peces del río Atrato, zona hidrogeográfica del Caribe, Colombia. Biota Colombiana, 7: 143-154.

Miles, C. 1943. Estudio económico y ecológico de los peces de agua dulce del Valle del Cauca. Cali: Secretaría de Agricultura y Fomento del Departamento del Valle del Cauca, 97p.

Miles, C. 1947. Los peces del rio Magdalena: "A field book of Magdalena fishes”. Bogotá, Editorial el Gráfico, 214p.

Mojica, J. I., C. Castellanos, S. Usma \& R. Álvarez (Eds.). 2002. Libro Rojo de peces dulceacuícolas de Colombia. La serie de libros rojos de especies amenazadas de Colombia. Instituto de Ciencias Naturales, Universidad Nacional de Colombia, Ministerio de Medio Ambiente, Bogotá, 289p.

Myers, G. S. 1930. Fishes from the upper Rio Meta basin, Colombia. Proceedings of the Biological Society of Washington, 43: 65-72.

Ortega, H. \& R. P. Vari. 1986. Annotated checklist of the freshwater fishes of Peru. Smithsonian Contributions to Zoology, 437: 1-24.

Ortega-Lara, A., S. Usma, P. A. Bonilla \& N. L. Santos. 2006. Peces de la cuenca del Río Cauca, Colombia. Biota Colombiana, 7: 39-54.

Parenti, L. R. 1981. A Phylogenetic and Biogeographic Analysis of Cyprinodontiform fishes (Teleostei, Atherinomorpha). Bulletin of the American Museum of Natural History, 168: 1-557.

Pavanelli, C. S. 1999. Revisão taxonômica da família Parodontidae (Ostariophysi: Characiformes). Unpublished Ph.D. Dissertation, Universidade Federal de São Carlos, São Carlos, Brazil, 332p.

Pavanelli, C. S. 2003. Family Parodontidae (Parodontids). Pp. 46-50. In: R. E. Reis, S. O. Kullander \& C. Ferraris, Jr. (Eds.). Check list of the freshwater fishes of South and Central America. Edipucrs, Porto Alegre, 729p.

Pavanelli, C. S. \& H. A. Britski. 2003. Apareiodon Eigenmann, 1916 (Teleostei, Characiformes), from the Tocantins-Araguaia Basin, with description of three New Species. Copeia, 2003: 337-348.

Posada, A. 1909. Los peces: Contribución al estudio de la fauna Colombiana. Estudios científicos: 285-322.

Roberts, T. R. 1974a. Dental polymorphism and systematics in Saccodon, Neotropical genus of freshwater fishes (Parodontidae, Characoidei). Proceedings of the Zoological Society of London, 173: 303-321.

Roberts, T. R. 1974b. Osteology and classification of the Neotropical characoid fishes of the families Hemiodontidae (including Anodontinae) and Parodontidae. Bulletin of the Museum of Comparative Zoology, 146: 411-472.

Román-Valencia, C. 1990. Lista y distribución de peces en la cuenca media del rio Atrato, Chocó, Colombia. Caldasia, 16: 201-208.

Schultz, L. P. 1944. The fishes of the family Characinidae from Venezuela, with descriptions of seventeen new forms. Proceedings of the United States National Museum, 95: 235-367.

Starnes, W. C. \& I. Schindler. 1993. Comments on the genus Apareiodon Eigenmann (Characiformes: Parodontidae) with the description of a new species from the Gran Sabana region of Eastern Venezuela. Copeia, 1993: 754-762.

Steindachner, F. 1879. Über einige neue und seltene Fisch-Arten aus den K. K. Zoologischen Museen zu Wien, Stuttgart und Warschau. Denkschriften der athematischNaturwissenschaftlinchen Classe der Kaiserlichen Akademie der Wissenschaften in Wein, 41: 1-52.

Taylor, W. R. \& G. C. van Dyke. 1985. Revised procedures for staining and clearing small fishes and other vertebrates for bone and cartilage study. Cybium, 9: 107-119.

Wiley, M. L. \& B. B. Collette. 1970. Breeding tubercles and contact organs in fishes: their occurrence, structure and significance. Bulletin of the American Museum of Natural History, 143: 1-216.

Villa-Navarro, F. A., P. T. Zúñiga, D. Castro, J. E. García, L. J. García \& M. E. Herrada. 2006. Peces del Alto Magdalena, cuenca del Río Magdalena, Colombia. Biota Colombiana, 7: 3-21.

Zanata, A. \& R. P. Vari, 2005. The family Alestidae (Ostariophysi, Characiformes): a phylogenetic analysis of a trans-Atlantic clade. Zoological Journal of the Linnean Society, 145: 1-144.

Submitted July 21, 2009 Resubmitted April 2, 2011

Accepted October 7, 2011

Published December 26, 2011 